\title{
Source Mechanisms and stress field of the 2017 Ayvacık/Çanakkale earthquake sequence in NW Turkey
}

\author{
Ethem Görgün*,1, Doğan Kalafat ${ }^{2}$, Kıvanç Kekovalı² \\ (1) Department of Geophysical Engineering, Istanbul University-Cerrahpaşa, Büyükçekmece Campus, 34500, Istanbul, \\ Turkey \\ (2) Boğaziçi University, Kandilli Observatory and Earthquake Research Institute, 34684 Çengelköy, Istanbul, Turkey
}

Article history: received May 3, 2019; accepted January 13, 2020

\begin{abstract}
Ayvacık district of Çanakkale province was hit by four moderate size earthquakes on 6 February 2017 03:51 $\mathrm{M}_{\mathrm{w}}$ 5.2, 6 February 2017 10:58 $\mathrm{M}_{\mathrm{w}}$ 5.1, 7 February 2017 02:24 $\mathrm{M}_{\mathrm{w}}$ 5.2, 12 February 2017 13:48 $M_{w}$ 5.3. Centroid moment tensor solutions for 60 events with moment magnitudes $\left(M_{w}\right)$ between 3.4 and 5.3 are computed by applying a waveform inversion method on data from the Turkish and Greek broadband seismic networks. The time span of data covers the period between 1 January and 28 February 2017. The mainshock is a shallow focus normal event with strike-slip component at a depth of $10 \mathrm{~km}$. Focal depths of aftershocks range from 3 to $24 \mathrm{~km}$. The seismic moment $\left(\mathrm{M}_{\mathrm{O}}\right)$ of the mainshock is estimated as $7.62 \times 10^{16} \mathrm{Nm}$. The calculated rupture duration of the Ayvacık mainshock is $3 \mathrm{~s}$. The focal mechanisms of the aftershocks are mainly normal faulting with a minor strike-slip component. The geometry of focal mechanisms reveals a normal faulting regime with NE-SW trending direction of $T$-axis in the entire activated region. We perform stress tensor inversion to acquire more accurate picture for the regional stress field. The stress tensor inversion results indicate a predominant normal stress regime with a WNW-ESE oriented maximum horizontal compressive stress $\left(\mathrm{S}_{\mathrm{H}}\right)$. With respect the newly determined focal mechanisms, the effect of the propagation of the North Anatolian Fault into Aegean Sea is very clearly pronounced. According to the double-difference relocation algorithm for the 2017 Ayvacık seismic sequence, ten clusters are revealed. In order to find these clusters, we use HypoDD software. According to the relative relocations from HypoDD, we define 10 clusters along the five profiles. The aftershock activity in the observation period between 1 January and 28 February 2017 extends from $\mathrm{W}$ to $\mathrm{E}$ direction. Seismic cross-sections indicate that a complex pattern of the hypocenter distribution with the ruptured segments. The western cluster is associated with a fault plane trending mainly N$\mathrm{S}$ and dipping vertical, while the eastern is related to a fault plane trending NE-SW and dipping towards NW. The best constrained focal depths operate in the approximate depth range from 3 to $24 \mathrm{~km}$. Coulomb stress analysis is performed to calculate the cumulative effect of all the earthquakes of the swarm and correlate it_with the activated region. Positive lobes with stress more than 3 bars are obtained, these values are large enough to trigger failure towards NW-SE of the swarm activity.
\end{abstract}

Keywords: Aftershock; Biga Peninsula; Coulomb Stress Analysis; Focal Mechanism; Moment Tensor Inversion; Aegean Sea earthquake; Stress tensor inversion. 


\section{Ethem Görgün et al.}

\section{Introduction}

The Ayvacık earthquake (EQ) occurred at 03:51:40.0 GMT on 6 February 2017 in Çanakkale province. The mainshock was a moderate size $\left(\mathrm{M}_{\mathrm{W}}=5.2\right)$ event at a depth of $10 \mathrm{~km}$. The Ayvacık EQ is directly located in the westernmost part of Biga Peninsula (BP) along the western North Anatolian Fault (NAF) strike-slip fault system (Figure 1a). Biga Peninsula is one of the most seismically active parts of the northwestern Anatolia. It is dominated by a series of strike-slip structures bounded by normal or oblique faults [McKenzie, 1978; Şengör et al., 1985; Taymaz et al., 1991; Le Pichon et al., 1995; Barka et al., 1997; Kreemer et al., 2004; Gürer et al., 2006; Kürçer et al., 2008; Ateş et al., 2009; Le Pichon and Kreemer, 2010; Fichtner et al., 2013; Selim and Tüysüz, 2013; Vanacore et al., 2013; Kind et al., 2015]. The main seismotectonic structures of the BP region are the Edremit Fault Zone (EFZ), Çan-Biga Fault (ÇBF), Evciler Fault (EF), Gülpınar Fault (GF) and Kestanbol Fault (KF) that compose transform plate boundaries where the Eurasian plate (EU) to the north is sliding relative to the Anatolian (AT) and Aegean Sea plates (AS) to the south (inset in Figure 1a and b). The NAFZ is one of the most active transform faults worldwide extending along $1600 \mathrm{~km}$ from eastern Anatolia to the Aegean Sea (Figure 1a). The direction of slip corresponds well with the Global Positioning System (GPS) derived 25-30 $\mathrm{mm} \mathrm{yr}^{-1}$ westward motion of the Anatolian Block with respect to Eurasia [McClusky et al., 2000; Reilinger et al., 2006]. The deformation zone associated with the transform is very wide from the Thrace to Aegean Graben system [Taymaz et al., 1991; Kreemer et al., 2004; Nyst and Thatcher, 2004; Gürer et al., 2006; Selim and Tüysüz, 2013]. Approximately $45^{\circ} \mathrm{NE}$ trend is observed as a strike-slip deformation along the BP. Strike-slip motion is transformed into normal on southwest part of the BP (see Figure 1b) [Kiratzi, 2002; Kreemer et al., 2004; Gürer et al., 2006; Aydoğan, 2007]. BP is located SW of Marmara region describing the southern branch of NAFZ (Figure 1). Figure 1b indicates an overview on the seismotectonic settings of BP region with Aegean Sea. BP forms the southwestern part of the Marmara Sea. In this region, it is correlated a wide strike-slip fault zone with an oblique motion [Erdik et al., 2004; Bohnhoff et al., 2016]. The focal mechanisms of recent moderate-size

a)

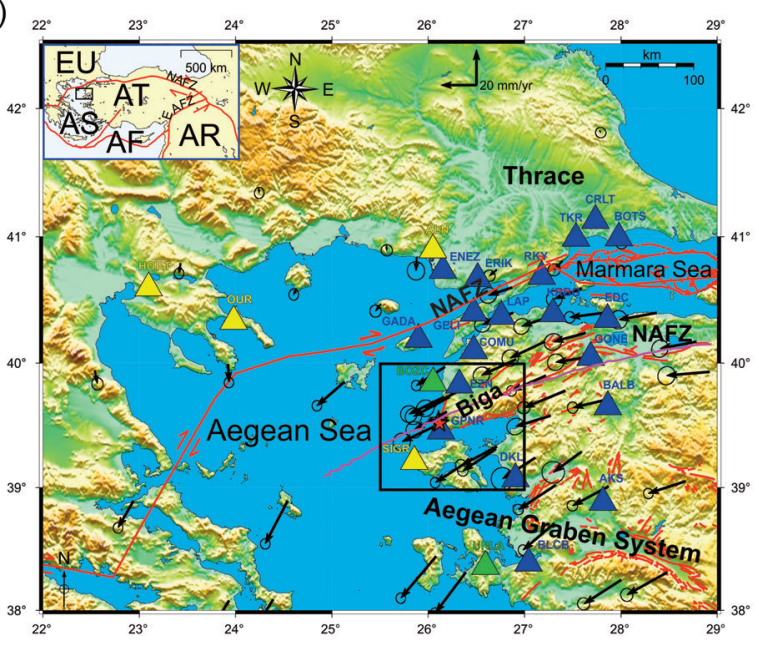

b)

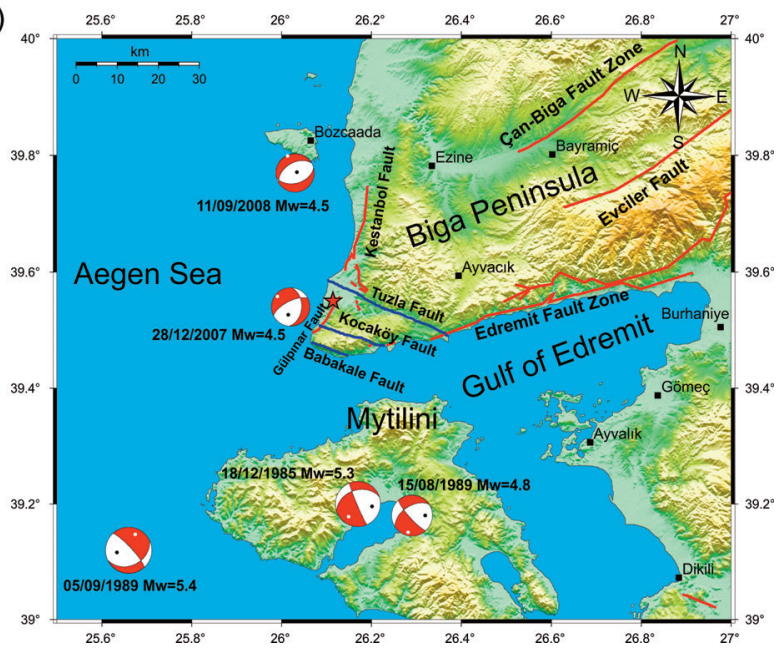

Figure 1. a) Tectonic map of northern Aegean Sea showing GPS velocities with respect to Eurasia and 95\% confidence ellipses for eastern Anatolia [McClusky et al., 2000; Reilinger et al., 2006]. Seismically active faults are shown by red lines [Şaroğlu et al., 1992]. Blue, green and yellow triangles with station codes depict locations of the KOERI, AFAD and AUTH broadband seismic stations, respectively. The epicenter of the 2017 Ayvacik $M_{w}$ 5.2 EQ at 03:51 is indicated by the red star. The inset in the above left shows whole Turkey. Significant active faults are indicated by the red lines in Biga Peninsula [Emre et al., 2013]. Two closely spaced red single arrows display shear sense of major faults (NAT: North Aegean Trough, NAFZ: North Anatolian Fault Zone, EAFZ: East Anatolian Fault Zone). Boundaries (heavy colored red lines) of the Aegean Sea (AS) and Anatolian (AT) plates, which are surrounded by the African (AF), Arabian (AR) and Eurasian (EU) plates (Bird, 2003). The solid black rectangle shows the study area, which is enlarged in Fig. 1a.b) For reference, focal mechanisms of the previous significant earthquakes are plotted [Kalafat et al., 2009]. Black and white circles on beach-balls exhibit $P$ and $T$-axes, respectively. Red star represents the 6 February $2017 M_{w} 5.2$ 03:51 mainshock. 
earthquakes that have occurred since 1985 around the BP is shown in Figure $1 \mathrm{~b}$ [Kalafat et al., 2009]. The distribution of these epicenters indicates a low activity compared with Marmara Sea [Erdik et al., 2004; Bohnhoff et al., 2016]. These earthquakes are mostly upper plate events (depth $\leq 25 \mathrm{~km}$ ) [Kalafat et al., 2009]. The seismic pattern of BP and surrounding area is generally characterized by moderate and large size events [Kalafat et al., 2009]. The focal mechanisms of some moderate recent events are related to the NAFZ strike-slip and oblique system combination. We interpret their orientation and spatial distribution in terms of the major strike-slip fault with normal motions. Ganas et al. [2018] stated that Ayvacık EQ has normal slip kinematics, dimensions of 6 by 6 km (length, width) and dips at $45^{\circ}$ according to geodetic inversion results. Their INSAR analysis also showed that there is a uniform slip of $28 \mathrm{~cm}$. Özden et al. [2018] also pointed out that analysis of the recent Ayvacık earthquake sequence indicates the domination of the normal faulting stress regime in the southern part of Biga Peninsula with a consistent NNEtrending $\sigma_{3}$ axis. Mesimeri et al. [2018] indicated that spatial distribution of Ayvacık EQ sequences revealed a south-dipping causative fault along with secondary and smaller antithetic segments. In this respect, the seismicity started at the western part and migrated to the eastern part to the activated area. Svigkas et al. [2019] also stated that geodetic observations constrained the rupture distribution of the main events and they found a single fault with striking $\mathrm{N} 110^{\circ} \mathrm{E}$ and dipping $\sim 40^{\circ}$ to SW.

In this study, a stress tensor inversion of earthquake focal mechanism data is performed to obtain a more accurate picture of the regional stress field. For this purpose, seismic waveforms at local and regional distances are used to calculate source parameters of the 60 events $\left(5.3 \geq \mathrm{M}_{\mathrm{w}} \geq 3.4\right)$ of the 2017 Ayvacık EQ sequence using the waveform inversion method [Nakano et al., 2008]. This provides additional information on the stress field that may improve kinematic models for the Ayvacık EQ area and thus develop the understanding of the Biga Peninsula local and regional tectonics. Furthermore, the double-difference relocation algorithm [Waldhauser and Ellsworth, 2000] and the Coulomb stress analysis [Toda et al., 2005] are applied to determine the expanded spatial distribution of the Ayvack EQ sequence. Determination of accurate stress field orientations and event locations using data from local and regional seismic networks are crucial for investigations of the seismotectonics in and around southwestern Marmara Sea region.

\section{Data and waveform inversion method}

Figure 1a displays the distribution of the Kandilli Observatory and Earthquake Research Institute (KOERI), Disaster and Emergency Management Presidency Earthquake Department (AFAD) and the Aristotle University of Thessaloniki (AUTH) broadband seismic stations used in this study. We use seismic records obtained from 24 KOERI stations (blue triangles), 2 AFAD stations (green triangles) and 4 AUTH (yellow triangles) stations in this study (see Figure 1a).

Centroid moment tensor (CMT) solutions of earthquakes in the Ayvacık region are computed using the waveform inversion method developed by Nakano et al. [2008]. In this approach, if the location yielding a minimum residual lies at the edge of a search area, the grid is extended to surround the location of the minimum residual. When the location of minimum residual lies within a search area, a new search is performed around the location using a reduced grid spacing to find a detailed source location. The seismic moment and rupture duration are estimated from the deconvolved form of the moment function [Nakano et al., 2008; 2010].

Three-component seismograms are used for the inversion of the Ayvacık EQ sequence. Seismograms with good data quality (high signal-to-noise ratio) are selected. The average number of waveforms used for the CMT analysis is 10. The observed velocity seismograms are corrected for instrument response and then integrated in time to obtain the displacement seismograms. Waveforms are bandpass filtered between 20 and $50 \mathrm{~s}$ and decimated to a sampling frequency of $0.5 \mathrm{~Hz}$. A total data length of $512 \mathrm{~s}$ ( 256 data points in each channel) is used for the inversion. Green's functions are generated using the discrete wavenumber method [Bouchon, 1979], assuming the crustal structure model of Akyol et al. [2006] for the calculation. The synthetics are calculated for a horizontally layered structure given in Table 1. Green's functions are computed for every $10 \mathrm{~km}$ of epicentral distance up to $1500 \mathrm{~km}$. At each of these radius steps, three-component displacements are calculated at every $1^{\circ}$ in azimuth for each basis of moment tensor. Green's functions are also calculated at every $5 \mathrm{~km}$ for source depths (hypocentral depth) shallower than $100 \mathrm{~km}$. For spatial grid search, hypocenter locations estimated by KOERI are used as an initial location. Adaptive grid spacings, in which the grid spacings are gradually decreased in each step of the search, are also applied. 


\section{Ethem Görgün et al.}

Spatial grid search is started with a horizontal grid spacing of $0.5^{\circ}$ and a vertical grid spacing of $10 \mathrm{~km}$. In the next step, the grid spacing is reduced to $0.2^{\circ}$ horizontally and $5 \mathrm{~km}$ vertically. Finally, the horizontal grid spacing is reduced to $0.1^{\circ}$ and vertical is $5 \mathrm{~km}$. At each grid point, the fault and slip orientation parameters (strike, dip and rake angles) are searched in $5^{\circ}$ steps. For each combination of source location, fault and slip orientation parameters, the waveform inversion is carried out to estimate the best-fitting source parameters (see for details Nakano et al., [2008] and Nakano et al., [2010]).

The CMT solutions are obtained using data not only from stations in Turkey but also from Greece (yellow triangles in Figure 1a), and therefore azimuthal coverage is sufficient. The inversion method of Nakano et al. [2008] uses the double-couple constraint, which stabilizes the inversion solution and reduces the trade-off between source location and non-double-couple components (see for detail Nakano et al. [2008]). Furthermore, all stations used are located in similar crustal structures as Thrace and Greece thus; possible effects of the structural contrast may be minimized. Determination of accurate source parameters, especially source locations, using data from the local and regional seismic network are crucial for investigations of the seismotectonics in and around Turkey and Greece.

\begin{tabular}{cc}
$\boldsymbol{V}_{\boldsymbol{p}}\left(\mathbf{k m ~ s}^{\mathbf{- 1}}\right)$ & $\boldsymbol{H}(\mathbf{k m})$ \\
\hline 4.73 & $0.0-1.5$ \\
\hline 5.06 & $1.5-3.0$ \\
\hline 5.84 & $3.0-5.0$ \\
\hline 6.00 & $5.0-15.0$ \\
\hline 6.25 & $15.0-21.0$ \\
\hline 6.43 & $21.0-29.0$ \\
\hline 7.80 & $29.0-$ \\
\hline
\end{tabular}

Table 1. Crustal model used to estimate the source parameters of the mainshock and its aftershocks. $V_{p}$ and $H$ are $P$-wave velocity and thickness of the layers, respectively.

\section{Stress tensor inversion}

The stress tensor has six unknowns, either three principal stresses and orientations, or three normal and three shear stress components (e.g., Zang and Stephansson [2010]). Four of the unknowns are resolved by the inversion of the stress tensor, the fifth unknown is calculated by the assumption that slip occurs in the direction of maximum shear stress [Wallace, 1951; Bott, 1959] and the sixth unknown is usually resolved using the assumption that the stress tensor is homogeneous and constant in the binning region throughout the time interval of interest.

In this study, the technique of Michael $[1984 ; 1987]$ is applied to the selected 60 events (residuals are smaller than 0.4 according to Nakano et al., [2006] criteria; Table 2). The Michael-approach provides a more appropriate estimate of uncertainty, compare to Gephart and Forsyth [1984] approach [Hardebeck and Hauksson, 2001] The algorithm uses the statistical method of bootstrap re-sampling and allows determining the orientation of the three principal stresses $\left(\sigma_{1}=\right.$ maximum principal compressive stress, $\sigma_{2}=$ intermediate and $\sigma_{3}=$ minimum) as well as the stress ratio $R=\left(\sigma_{2^{-}} \sigma_{3}\right) /\left(\sigma_{1^{-}} \sigma_{3}\right)$, also called relative stress magnitude [Bott, 1959]. The $R$ is defined using the standard geologic/geophysical notation with compressive stress positive and $\sigma_{1}>\sigma_{2}>\sigma_{3}$ [Zoback, 1992]. The stress ratio $(R)$ ranges from 0 to 1 . Values of $R<0.5$ and $R>0.5$ indicate a transpressional and transtensional regime, respectively. All parameters are determined by finding the best fitting stress tensor to the observed focal mechanisms. Assumptions that must be fulfilled by the input data are: (1) stress is uniform in the area of interest during the observed time interval, however this assumption cannot be entirely valid given the diversity and complexity of the structures, (2) earthquakes are shear-dislocations on pre-existing faults, (3) similar shear stress magnitude are present on each fault and (4) slip occurs in the direction of the resolved shear stress on the fault plane. When analyzing real data sets, the uncertainties of the retrieved stress directions, the shape ratio, the fault selection and overall friction on faults are verified by the bootstrap method as proposed by Michael [1987] and Vavryčuk [2014]. Here the uncertainties are calculated as the maximum differences between the results of the inversion for noisefree and noisy data with 1000 noise realizations. This method is convenient for several reasons. First, it can take into 
account the case when some nodal planes are more uncertain than the others by specifying differently noise levels for the fault orientations and slip directions. And secondly, the obtained uncertainties are more realistic. The efficiency of the iterative inversion was tested on the Ayvacik data. The method worked well and produced a significantly more accurate shape ratio than the inversion of the focal mechanisms with randomly selected faults.

To quantify the misfit between the best stress tensor and the data, the angle between the calculated slip vector from stress tensor inversion and observed slip vector from fault plane solutions is used. This angle is referred to as $\beta$. The angle $\bar{\beta}$ refers to the mean value of $\beta$ for the data in a single inversion [Michael, 1987]. A synthetic control study showed that the amount of heterogeneity in the stress field could be characterized by the average misfit between the observed and predicted slip directions $(\bar{\beta})$ [Michael et al., 1990]. If $\bar{\beta} \leq 33^{\circ}$, stress tensors are spatially uniform. If $\bar{\beta}>33^{\circ}$, the inversion result is interpreted in terms of a spatially heterogeneous state of stress (Michael, 1991). This $33^{\circ}$ marks the transition from an uniform stress field to a heterogeneous stress field. In our study, stress tensor inversion results give $\bar{\beta}$ angles smaller than $33^{\circ}$. Heterogeneity of the stress field was documented in the average misfit level of the inversion. For each stress inversion, 2000 bootstrap iterations are performed.

Michael's algorithm is quite fast and accurate when compensating directions of the principal stresses. It gives a reasonable accuracy even for randomly selected fault planes in focal mechanisms. For example, Vavryčuk [2014] indicated that the principal stress directions are determined with a similar accuracy regardless of whether the faults are randomly selected from nodal planes or correctly identified by the inversion. The behavior of the shape ratio is, however, remarkably different. Data with randomly selected faults yield a broad distribution of the shape ratio with its maximum significantly biased as compared to the inversion with correctly selected faults. The maximum error is 44 and 12 percent for randomly and correctly selected faults, respectively. He calculated 1000 realizations of noise which produced an accuracy similar to that of the retrieved focal mechanisms (mean error of $6^{\circ}$ in the fault normal and slip direction). However, the accuracy of the stress ratio is significantly lowered when the fault planes are not correctly chosen. The stress ratio is more sensitive to the correct choice of the fault plane than the principal stress directions and substituting the faults by the auxiliary nodal planes introduces high errors [Lund and Slunga, 1999; Vavryčuk, 2014]. This difficulty is removed by modifying Michael's algorithm and inverting jointly for stress and for fault orientations [Vavryčuk, 2014]. The fault orientations are determined by applying the fault instability constraint and the stress is calculated in iterations. As a by-product, overall friction on faults is determined. Vavryčuk [2014] showed that the new iterative stress inversion is fast and accurate, and performs much better than the standard linear inversion. Since the iterative stress inversion is based on Michael's method, it can easily be implemented in these codes enhancing their accuracy. Vavryčuk [2014] proposed the MATLAB code of this inversion called STRESSINVERSE that is provided on the web page (http://www.ig.cas.cz/stress-inverse).

\section{Results}

\subsection{Relocation of hypocenters}

We locate all earthquakes using the 1-D (P-and S-wave) velocity model of Akyol et al. [2006]. We choose only events with at least 5 stations with $5 \mathrm{P}$ - and $2 \mathrm{~S}$-phases, hypocenter parameters with RMS errors $<0.5 \mathrm{~s}$, azimuthal gap $<180^{\circ}$ and horizontal and vertical errors $<1 \mathrm{~km}$, using the HYPOCENTER earthquake location program [Lienert and Havskov, 1995]. 3140 events which are recorded by at least five stations for two months period following the date of 1 January 2017. We calculate the absolute hypocentral parameters of aftershocks with the hypocenter location algorithm described by Lienert and Havskov [1995]. The catalogue covers the period from 1 January to 28 February 2017 for shallow earthquakes with hypocentral depth $<25 \mathrm{~km}$. The catalogue consists of 3140 events. The average horizontal and vertical uncertainties of the 3140 events $\left(\mathrm{M}_{1} \geq 2.0\right)$ are found to be 3 and $4 \mathrm{~km}$, respectively. In minimizing the errors in the location parameters, network geometry, phase reading quality and uncertainties in the crustal structure are restricting factors. Relative earthquake location methods can improve absolute hypocenter locations. For this purpose, the double-difference relocation algorithm HypoDD, Waldhauser and Ellsworth, [2000] is used. The algorithm assumes that the difference in travel times for two close events observed at one station can be connected to the spatial offset between the events with high accuracy. Absolute location parameters of aftershocks and P/S travel time differences between the event pairs are used for the inputs. Relative location errors of the 2326 relocated events are smaller than $1 \mathrm{~km}$ in horizontal and vertical directions. 


\section{Ethem Görgün et al.}

We divided the catalogue into two parts. The first part of the catalogue ranges from 1 January to 6 February. This part exhibits the seismicity prior to Ayvacik EQ sequence. The second part of the catalogue includes aftershocks of the 2017 Ayvacık EQ sequence. Figure 2 and Figure 3 display the seismicity before and after the 6 February 2017 Ayvacık EQ sequence, respectively. From the spatial distribution of the epicenters (Figure 2), it is observed that the epicenters indicate a prominent NW-SE alignment. The along strike dimension of the activated zone is $\sim 30 \mathrm{~km}$ and its width is greater than $10 \mathrm{~km}$, prior to the February 2017 Ayvacık mainshock $\left(\mathrm{M}_{\mathrm{w}}=5.2\right)$. This observation is also represented in the depth cross-section along N-S direction (Figure 2, profile A-A', indicated by blue). The event depths range from 3 to $24 \mathrm{~km}$.

A number of aftershocks are located off-shore (A-A' and B-B' profiles) with respect to the main aftershock cluster. The swarm activity in the observation period between 6 and 28 February extends from the $\mathrm{W}$ to the E direction
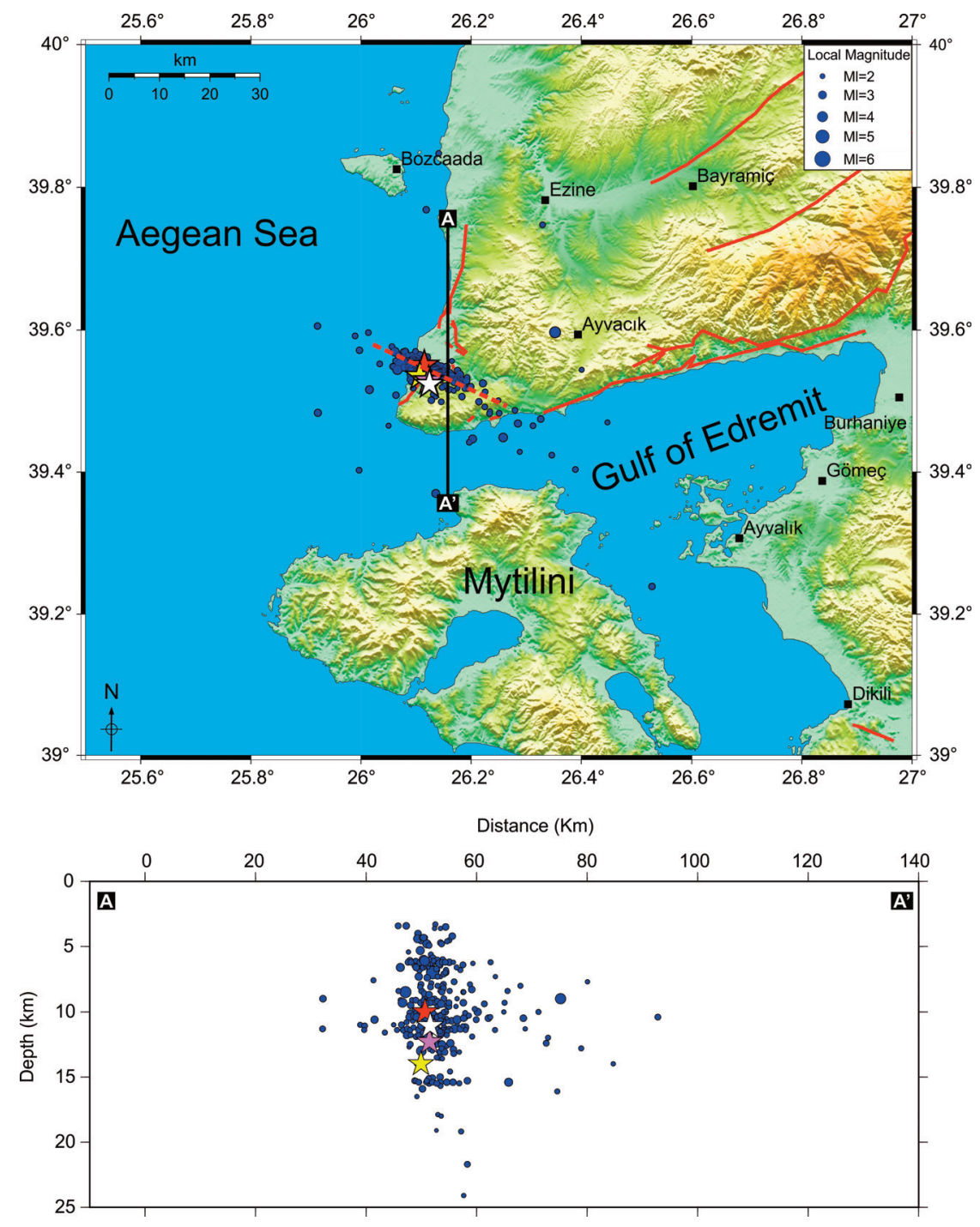

Figure 2. a) Seismicity distribution of the 2017 Ayvacık EQ area prior to 6 February 2017. Blue circles represent earthquake epicenters. A-A' is the depth cross-section profile. Cross-section is perpendicular to the strike of the fault rupture (red dashed line). b) Depth cross-section profile for A-A' in the upper topographic map. The event catalog covers the period between 1 January and 6 February 2017. The earthquakes prior to the mainshock operates in the depth range from 4 to $20 \mathrm{~km}$ for $M_{l} \geq 2.0$ events. Orientation of the distribution of pioneer events trends NW-SE. The pioneer earthquake cluster is clearly depicted in the $\sim 30 \mathrm{~km}$ width vertical zone of the cross-section. The size of the epicenters is proportional to magnitude. Red lines indicated active faults along Biga Peninsula [Emre et al., 2013]. Red, yellow, pink and white stars represent 6 February 2017 03:51 Mw 5.2, 6 February 2017 10:58 Mw 5.1, 7 February 2017 02:24 Mw 5.2, 12 February 2017 13:48 Mw 5.3 mainshocks, respectively. 
(Figure 3). This observation is also shown in the cross-section perpendicular to the fault rupture (Figure 3, profile A-A', B-B', C-C', D-D' and E-E'). The best constrained focal depths (from waveform modelling and HypoDD analysis) indicate that the aftershock sequence is mainly confined in the crust (depth $<25 \mathrm{~km}$ ) and is running in the approximate depth range from 3 to $24 \mathrm{~km}$. In order to investigate evaluation of aftershocks along the Ayvacik EQ area, we examine spatial distribution of aftershocks along 5 profiles. Aftershocks are clearly activated in the $\sim 50 \mathrm{~km}$ length and $\sim 10 \mathrm{~km}$ width of fault rupture zone (Figure 3). Along these 5 profiles, we detect ten secondary fault segments in the study area based on double-difference algorithm. Ten secondary fault segments are related to visual inspection after application of double difference algorithm. We indicate main active faults (red lines in Figure 3) along the Ayvacık earthquake region and Figure 3 also shows a possible Ayvacık earthquake rupture zone (white dashed line) according to aftershock distribution. We display 3D view of aftershock distribution for Ayvacık EQ sequence in Figure 3 in accordance with to the 5 profiles.

In the westernmost end of the main cluster, the seismicity occurred in a zone of $\sim 10 \mathrm{~km}$ wide and the depths of aftershock are found to be between 5 and $20 \mathrm{~km}$ (Figure 3, profile A-A'; indicated by blue). The middle and easternmost of the clusters (profile B-B'; indicated by red, profile C-C'; indicated by yellow, profile D-D'; indicated by purple and profile E-E' indicated by black) covers aftershocks occurring at depths of 3 and $24 \mathrm{~km}$. The dip angle of the NE-SW nodal plane complies with the slope of the aftershock focal depths on the A-A' and D-D' cross-section in Figure 3. Moreover, profiles of B-B' and C-C' exhibit also NW directions for dip angles of ruptured segments. Furthermore, Figure $4 \mathrm{a}$ and $\mathrm{b}$ indicates cumulative number of $\mathrm{EQ}$ as a function of time before and after the February 6 mainshock, respectively. Figure 4 also present clearly temporal variations of the events occurred before and after the February 6 mainshock for the entire EQ catalogue.
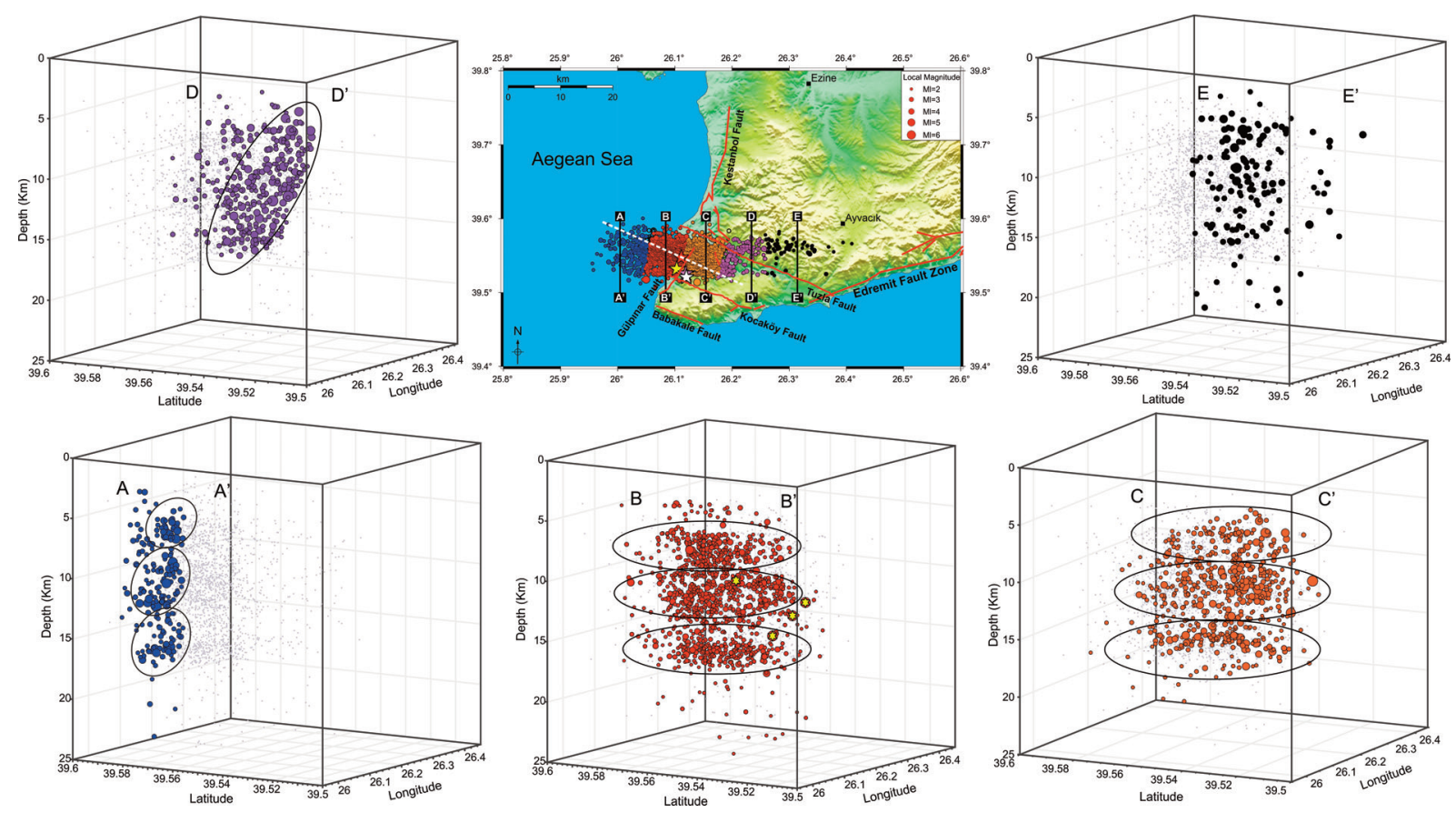

Figure 3. Epicenters of the 2017 Ayvacık EQ sequence. The size of the epicenters is proportional to magnitude. Profiles labelled A-A', B-B', C-C', D-D' and E-E' represent directions of seismic cross-sections. The colours of the hypocenters are related to the seismic profiles in accordance with size and local area distributions of aftershocks (i.e., A-A' blue, B-B' red, C-C' orange, D-D' purple and E-E' black). Seismic profiles are generally perpendicular to the aftershock orientations (E-W direction). Seismic cross-section along A-A', B-B', C-C', D-D' and E-E' directions are shown at the bottom, left and right sides in 3D view. Red lines and white dashed line indicate active fault segments and possible postseismic rupture along the study region after the Ayvacık mainshock (6 February 2018), respectively. 


\section{Ethem Görgün et al.}
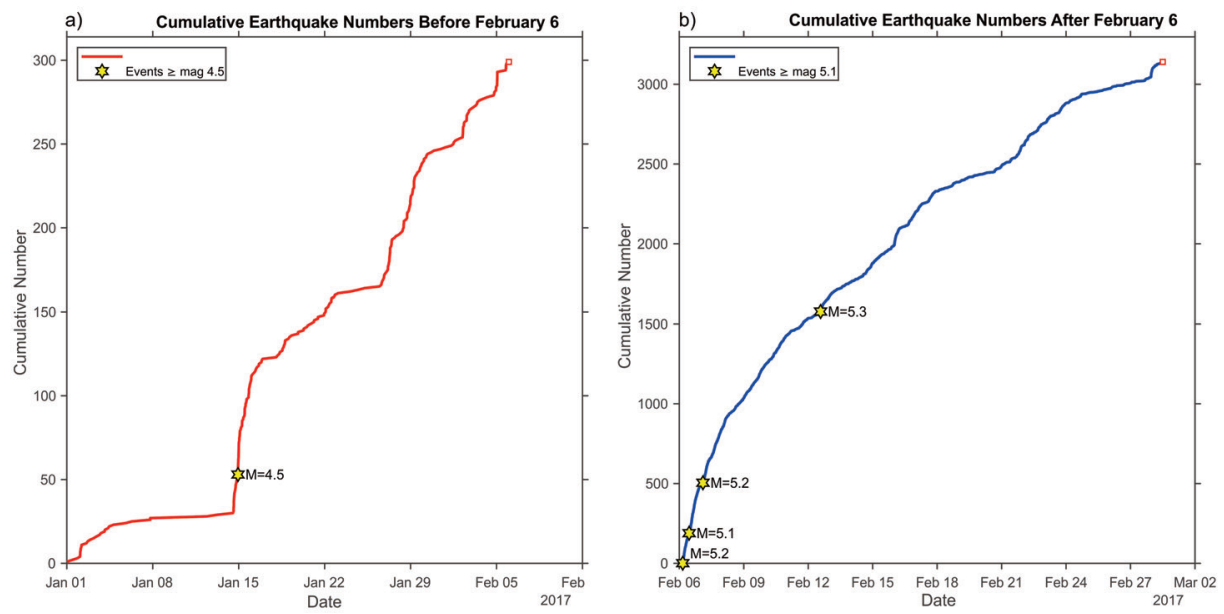

Figure 4. a) Cumulative number of EQ prior to the February 6 mainshock and b) Cumulative EQ number after the February 6 mainshock. Yellow stars indicate $M w \geq 4.5$ events.

\subsection{The February 2017 Ayvacık earthquake sequence}

In this section, we present the February 2017 Ayvacik events $\left(\mathrm{M}_{\mathrm{w}} \geq 3.4\right)$ along the SW Marmara region near Çanakkale province. The four largest event of the $\mathrm{EQ}$ sequence are chosen as an example. It is interesting to present these large size events and their focal mechanisms are different from the ones of aftershocks. These events are representative of the data set. The results of moment tensor solution for the 60 selected events are given in Table 2. From the spatial distribution of the CMT solutions (Figure 5), we observe a prominent NE-SW alignment of nodal planes. The along-strike dimension of the activated zone is $\sim 30 \mathrm{~km}$, and its width is approximately $15 \mathrm{~km}$. The moment magnitudes (Mw) range from 3.4 to 5.3. Figures 5 and 6 display 60 fault plane solutions in lower-hemisphere equal-area/angle projection in map view and cross section (profile $\mathrm{A}-\mathrm{A}^{\prime}$ ), respectively.

First, the source centroid location and focal mechanism of these events are estimated. Figures 5 and 6 show the best fitting source location of 60 events obtained from the waveform inversion. Using the hypocenter location determined by KOERI as an initial source location, the waveform inversion searched for the best-fitting source parameters. Revised source locations vary in average $4 \mathrm{~km}$ horizontally and $5 \mathrm{~km}$ vertically with respect to the initial locations of KOERI, but this variation does not change the general pattern in seismicity. Location differences depend on velocity model, station coverage and number of stations use to calculate the hypocenter. Data from some of near stations (distance $<50 \mathrm{~km}$ ) are not used because the waveforms are clipped or saturated. The focal mechanism of the 6 February $2017 \mathrm{M}_{\mathrm{w}} 5.203: 51 \mathrm{EQ}$ (event \#4, Table 2) obtained at the best fitting source location shows a normal motion with significant strike-slip component (Figure 7), characterized by a nodal plane with strike, dip and rake $333^{\circ}, 76^{\circ}$ and $-63^{\circ}$, respectively. Waveforms recorded by four stations (BZC, green triangle; EZN and GADA, blue triangle and SIGR, yellow triangle; Figure 1a), which are located at epicentral distances ranging from approximately 30 to $80 \mathrm{~km}$ are used. The seismic moment of the mainshock is estimated as $\mathrm{M}_{0}=7.62 \times 10^{16}$ $\mathrm{Nm}$, and the corresponding moment magnitude is $\mathrm{M}_{\mathrm{w}}=5.2$. The seismic moment function obtained from the waveform inversion is shown in Figure 7 (upper right). The rupture duration estimated from the moment function is $3 \mathrm{~s}$ (Figure 7, upper right side). Waveform fits between observed and synthetic seismograms calculated for the best fitting source parameters are also displayed in Figure 7 (Nakano et al., [2008] for details on the approach). Waveform fits are in good agreement with a normalized residual $(R)$ of 0.05 (Figure 7, lower left).

The 6 February 2017 10:58 $\mathrm{M}_{\mathrm{w}} 5.1$ event is investigated (event \#8, Table 2, Figure 8). Waveforms recorded by four stations which are located at epicentral distances ranging from 35 to $75 \mathrm{~km}$ used for the previous event. The seismic moment of the 10:58 event is estimated as $M_{0}=5.70 \times 10^{16} \mathrm{Nm}$, and the corresponding moment magnitude is $\mathrm{M}_{\mathrm{W}}=5.1$. This event is located at the $\mathrm{SW}$ of the $03: 51$ event. The estimated focal mechanism is indicated in Figure 8; a nodal plane corresponds to $300^{\circ}$ strike, $60^{\circ}$ dip and $-60^{\circ}$ rake angles. The focal mechanism of this event is normal faulting. This indicates that this event does not have the similar focal mechanism as the 03:51 event. 
The 2017 Ayvacik Earthquake Sequence

\begin{tabular}{|c|c|c|c|c|c|c|c|c|c|c|}
\hline No & Date & Time (GMT) & Lat $\left({ }^{\circ} \mathrm{N}\right)$ & Lon $\left({ }^{\circ} \mathrm{E}\right)$ & H (km) & $M_{w}$ & Str $\left({ }^{\circ}\right)$ & $\operatorname{Dip}\left({ }^{\circ}\right)$ & Rake $\left({ }^{\circ}\right)$ & $\boldsymbol{R}$ \\
\hline 1 & 14.01 .2017 & $22: 38: 59.4$ & 39.5488 & 26.1208 & 7.0 & 4.5 & 333 & 52 & 39 & 0.09 \\
\hline 2 & 15.01 .2017 & $06: 38: 48.9$ & 39.5595 & 26.0998 & 13.0 & 3.8 & 322 & 61 & -17 & 0.14 \\
\hline 3 & 30.01 .2017 & $06: 56: 16.2$ & 39.5965 & 26.3522 & 9.0 & 4.2 & 281 & 69 & -112 & 0.04 \\
\hline 4 & 06.02.2017 & $03: 51: 40.0$ & 39.5443 & 26.1068 & 10.0 & 5.2 & 333 & 76 & -63 & 0.05 \\
\hline 5 & 06.02.2017 & $03: 54: 52.5$ & 39.5343 & 26.1247 & 17.4 & 4.2 & 247 & 77 & -149 & 0.12 \\
\hline 6 & 06.02 .2017 & $04: 17: 28.6$ & 39.5463 & 26.1103 & 10.6 & 4.2 & 311 & 64 & -106 & 0.06 \\
\hline 7 & 06.02.2017 & $09: 42: 33.0$ & 39.5585 & 26.0935 & 13.0 & 3.5 & 283 & 61 & -98 & 0.08 \\
\hline 8 & 06.02 .2017 & 10:58:01.3 & 39.5287 & 26.0990 & 14.0 & 5.1 & 300 & 60 & -60 & 0.03 \\
\hline 9 & 06.02.2017 & $11: 03: 32.2$ & 39.5277 & 26.1177 & 10.0 & 4.4 & 324 & 47 & -105 & 0.04 \\
\hline 10 & 06.02 .2017 & $11: 36: 27.7$ & 39.5292 & 26.1348 & 9.3 & 3.7 & 212 & 33 & -114 & 0.14 \\
\hline 11 & 06.02.2017 & $11: 45: 00.9$ & 39.5310 & 26.0862 & 11.3 & 4.7 & 268 & 61 & -98 & 0.12 \\
\hline 12 & 06.02.2017 & $11: 54: 08.9$ & 39.5448 & 26.1402 & 9.6 & 3.7 & 267 & 52 & -141 & 0.06 \\
\hline 13 & 06.02.2017 & 12:18:07.4 & 39.5477 & 26.0783 & 6.5 & 4.1 & 314 & 76 & -94 & 0.09 \\
\hline 14 & 06.02.2017 & $12: 54: 04.9$ & 39.5477 & 26.0833 & 7.9 & 3.7 & 330 & 45 & -60 & 0.12 \\
\hline 15 & 06.02.2017 & 13:01:59.6 & 39.5387 & 26.1265 & 9.0 & 3.4 & 356 & 69 & -112 & 0.13 \\
\hline 16 & 06.02.2017 & $14: 23: 34.4$ & 39.5547 & 26.1078 & 7.0 & 3.6 & 237 & 52 & -141 & 0.16 \\
\hline 17 & 06.02 .2017 & $14: 58: 42.9$ & 39.5280 & 26.1177 & 10.6 & 3.9 & 315 & 45 & -60 & 0.08 \\
\hline 18 & 06.02 .2017 & $15: 23: 35.3$ & 39.5575 & 26.0725 & 7.3 & 3.7 & 276 & 52 & -117 & 0.09 \\
\hline 19 & 07.02 .2017 & 02:24:03.0 & 39.5227 & 26.1148 & 12.3 & 5.2 & 285 & 45 & -75 & 0.05 \\
\hline 20 & 07.02 .2017 & 03:16:31.0 & 39.5233 & 26.1348 & 15.9 & 3.7 & 210 & 47 & -159 & 0.11 \\
\hline 21 & 07.02 .2017 & $05: 15: 50.6$ & 39.5208 & 26.1548 & 12.7 & 4.3 & 252 & 52 & -141 & 0.06 \\
\hline 22 & 07.02.2017 & 05:17:08.2 & 39.5323 & 26.1635 & 11.5 & 4.5 & 309 & 47 & -105 & 0.13 \\
\hline 23 & 07.02.2017 & 06:04:39.0 & 39.5318 & 26.1348 & 11.4 & 3.6 & 284 & 21 & -134 & 0.18 \\
\hline 24 & 07.02 .2017 & 09:13:37.6 & 39.5310 & 26.1702 & 6.2 & 3.9 & 300 & 30 & -135 & 0.17 \\
\hline 25 & 07.02 .2017 & $14: 22: 13.4$ & 39.5393 & 26.1542 & 15.3 & 3.6 & 188 & 77 & -149 & 0.05 \\
\hline 26 & 07.02.2017 & $15: 11: 08.2$ & 39.5573 & 26.1038 & 15.9 & 3.9 & 240 & 45 & -165 & 0.09 \\
\hline 27 & 07.02.2017 & $15: 25: 25.3$ & 39.5247 & 26.1735 & 6.0 & 3.9 & 300 & 30 & -30 & 0.12 \\
\hline 28 & 07.02.2017 & $20: 16: 46.5$ & 39.5417 & 26.1455 & 13.4 & 3.7 & 15 & 75 & -75 & 0.14 \\
\hline 29 & 07.02 .2017 & 21:00:53.8 & 39.5307 & 26.1595 & 6.0 & 4.4 & 193 & 83 & -119 & 0.11 \\
\hline 30 & 07.02.2017 & $22: 53: 29.4$ & 39.5368 & 26.0322 & 12.2 & 4.3 & 360 & 30 & -30 & 0.06 \\
\hline 31 & 08.02.2017 & 01:33:11.2 & 39.5348 & 26.1667 & 15.8 & 4.0 & 210 & 30 & -180 & 0.10 \\
\hline 32 & 08.02.2017 & 01:33:42.5 & 39.5367 & 26.1415 & 11.0 & 3.9 & 240 & 60 & -15 & 0.12 \\
\hline 33 & 08.02.2017 & 01:38:03.2 & 39.5373 & 26.1495 & 10.7 & 4.8 & 240 & 30 & -75 & 0.05 \\
\hline 34 & 08.02.2017 & 02:16:13.7 & 39.5415 & 26.1410 & 11.3 & 4.5 & 180 & 45 & -180 & 0.09 \\
\hline 35 & 08.02.2017 & $04: 16: 24.1$ & 39.5450 & 26.1615 & 15.5 & 3.7 & 240 & 45 & -90 & 0.13 \\
\hline 36 & 08.02.2017 & $05: 44: 22.6$ & 39.5272 & 26.1507 & 16.2 & 3.6 & 357 & 76 & -117 & 0.15 \\
\hline 37 & 08.02.2017 & $15: 31: 50.1$ & 39.5343 & 26.1215 & 15.9 & 3.9 & 4 & 69 & -68 & 0.07 \\
\hline 38 & 09.02.2017 & $00: 37: 53.1$ & 39.5607 & 26.0783 & 16.1 & 3.6 & 270 & 45 & -30 & 0.14 \\
\hline 39 & 09.02.2017 & 10:13:10.2 & 39.5487 & 26.0413 & 7.1 & 3.9 & 225 & 45 & -90 & 0.05 \\
\hline 40 & 10.02 .2017 & $08: 55: 25.4$ & 39.5108 & 26.1348 & 9.5 & 4.8 & 266 & 41 & -131 & 0.09 \\
\hline 41 & 11.02 .2017 & $22: 01: 13.6$ & 39.5583 & 26.1228 & 8.6 & 4.1 & 75 & 60 & -180 & 0.11 \\
\hline 42 & 12.02 .2017 & $12: 14: 49.3$ & 39.5497 & 26.0565 & 11.0 & 3.8 & 237 & 76 & -117 & 0.08 \\
\hline 43 & 12.02 .2017 & $13: 48: 15.5$ & 39.5177 & 26.1160 & 11.1 & 5.3 & 310 & 60 & -70 & 0.05 \\
\hline 44 & 12.02 .2017 & $13: 50: 50.6$ & 39.5477 & 26.1348 & 14.3 & 4.1 & 23 & 61 & -163 & 0.09 \\
\hline 45 & 12.02.2017 & $18: 51: 00.6$ & 39.5588 & 26.1478 & 15.5 & 4.2 & 221 & 79 & -134 & 0.07 \\
\hline 46 & 12.02 .2017 & $22: 03: 36.7$ & 39.5527 & 26.0627 & 10.8 & 3.7 & 246 & 52 & -117 & 0.12 \\
\hline 47 & 12.02 .2017 & $23: 58: 36.5$ & 39.5803 & 26.0583 & 10.4 & 3.7 & 45 & 60 & -45 & 0.13 \\
\hline 48 & 16.02 .2017 & $00: 18: 59.8$ & 39.5143 & 26.0457 & 14.1 & 4.6 & 319 & 64 & -74 & 0.10 \\
\hline 49 & 23.02.2017 & $01: 55: 13.6$ & 39.5583 & 26.0707 & 7.3 & 4.4 & 60 & 45 & -15 & 0.07 \\
\hline 50 & 23.02.2017 & $18: 40: 14.2$ & 39.4960 & 26.2517 & 7.2 & 3.8 & 212 & 33 & -114 & 0.06 \\
\hline 51 & 26.02.2017 & $17: 50: 38.7$ & 39.5022 & 26.1348 & 12.6 & 3.7 & 330 & 60 & -75 & 0.03 \\
\hline 52 & 27.02.2017 & $22: 52: 23.0$ & 39.5025 & 26.0340 & 10.9 & 3.8 & 45 & 45 & -75 & 0.05 \\
\hline 53 & 28.02.2017 & $23: 26: 40.7$ & 39.4685 & 25.9770 & 7.5 & 4.1 & 0 & 75 & -90 & 0.12 \\
\hline 54 & 28.02.2017 & $23: 27: 32.7$ & 39.4577 & 25.9650 & 10.0 & 5.0 & 255 & 45 & -45 & 0.07 \\
\hline 55 & 28.02.2017 & $23: 30: 39.6$ & 39.5053 & 26.0735 & 15.7 & 3.8 & 315 & 60 & -45 & 0.13 \\
\hline 56 & 01.03.2017 & 00:05:19.3 & 39.4823 & 26.0085 & 15.0 & 3.6 & 219 & 33 & -152 & 0.10 \\
\hline 57 & 02.03.2017 & $05: 48: 41.0$ & 39.4907 & 26.0307 & 16.5 & 4.2 & 210 & 45 & -180 & 0.08 \\
\hline 58 & 10.03 .2017 & $06: 58: 55.4$ & 39.4577 & 26.2053 & 14.6 & 3.7 & 330 & 75 & -75 & 0.09 \\
\hline 59 & 20.03.2017 & 07:00:18.1 & 39.5445 & 26.0970 & 9.6 & 4.3 & 255 & 47 & -159 & 0.05 \\
\hline 60 & 20.03.2017 & $08: 01: 51.2$ & 39.5392 & 26.0875 & 10.0 & 3.8 & 284 & 21 & -134 & 0.09 \\
\hline
\end{tabular}

Table 2. Hypocenters and source parameters of the 2017 Ayvacik EQ sequence. $H$ is depth, $M_{w}$ is moment magnitude, Str is strike angle and $R$ is the normalized residual of waveform fitting. 


\section{Ethem Görgün et al.}

The compressional axis is NW-SE. The fits between observed and synthesized seismograms are also displayed in Fig 8. The small residual $(R=0.03)$ indicates that the observed seismograms are in good agreement with the synthetic ones (Figure 8, red and black seismograms).

The 7 February 2017 02:24 $\mathrm{M}_{\mathrm{w}} 5.2$ event is also examined using waveform inversion technique (event \#8, Table 2, Figure 9). The seismic moment of the $02: 24$ event is estimated as $M_{0}=6.70 \times 10^{16} \mathrm{Nm}$. This event is located at the SE of the 03:51 and 10:58 events. The focal mechanism of this event is computed as a pure normal fault with a compressional axis is E-W direction. The small residual $(R=0.05)$ exhibits that the observed seismograms are in good agreement with the synthetic ones (Figure 9, red and black seismograms).

The 12 February 2017 13:48 $\mathrm{M}_{\mathrm{w}} 5.3$ event is the largest EQ in the catalogue. We examined using waveform inversion technique same as former events (event \#43, Table 2, Figure 10). The depth of this event is shallow and comply with the former $\mathrm{M}_{\mathrm{w}}>5.0$ events. The seismic moment of the $13: 48$ event is estimated as $\mathrm{M}_{\mathrm{o}}=1.16 \times 10^{17}$ $\mathrm{Nm}$. This $\mathrm{EQ}$ is located at the same coordinates with 02:24 event. We estimate its focal mechanism as a normal fault with a compressional axis is NW-SE direction. The waveform fits between observed and synthesized seismograms are also shown in Figure 10 (red and black seismograms). We calculate a small residual $(R=0.05)$ for this event that observed seismograms correspond with the synthetic ones (Figure 10).

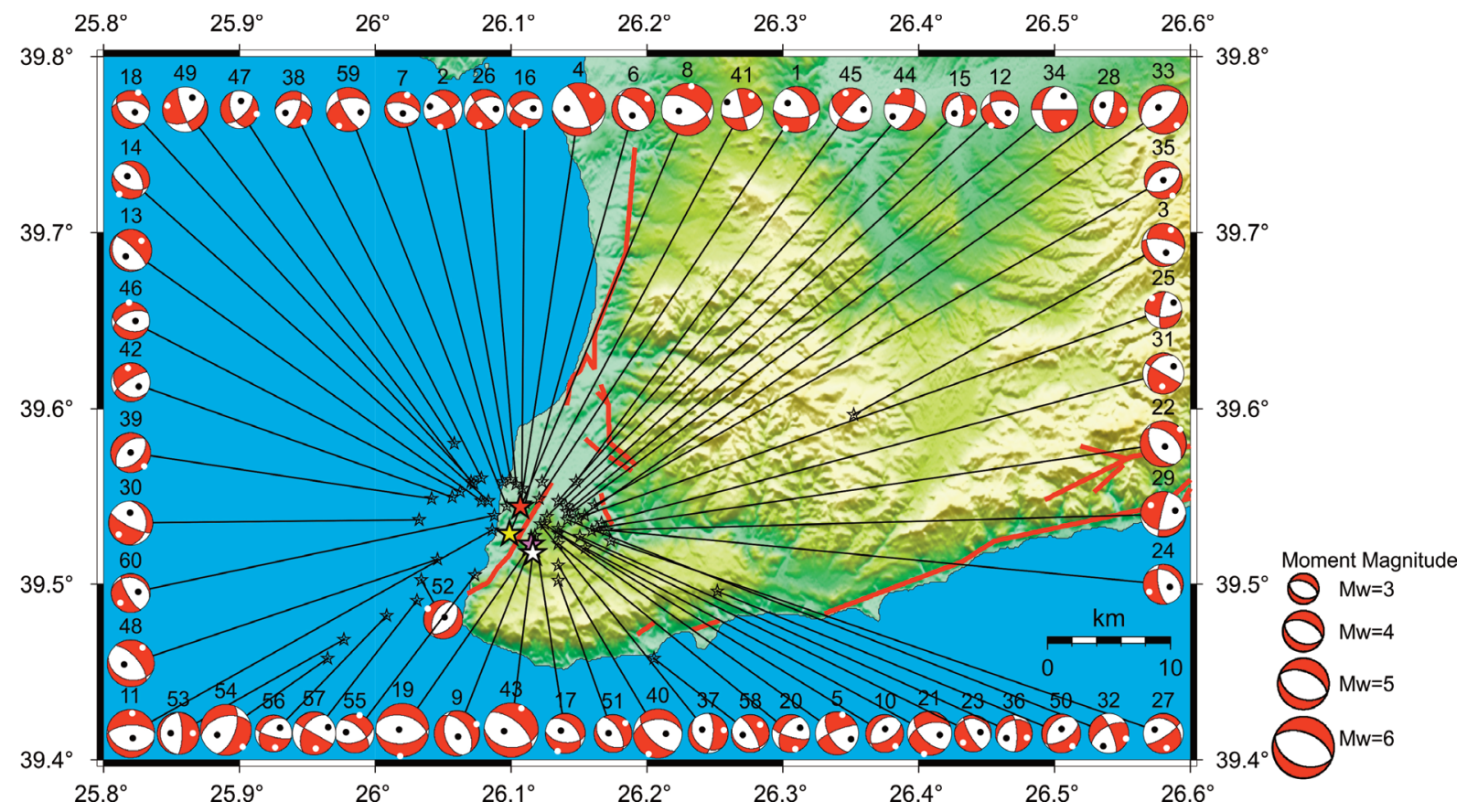

Figure 5. Topographic map view of CMT solutions obtained by the waveform inversion method developed by Nakano et al. [2008]. Focal mechanisms are projected on the lower hemisphere and scaled with magnitude. The time span of CMT data covers the period between 14 January and 20 March 2017. Black and white circles on beach-balls exhibit $P$ and $T$-axes, respectively. 6 February 2017 03:51 Mw 5.2, 6 February 2017 10:58 Mw 5.1, 7 February 2017 02:24 Mw 5.2, 12 February 2017 13:48 Mw 5.3. 


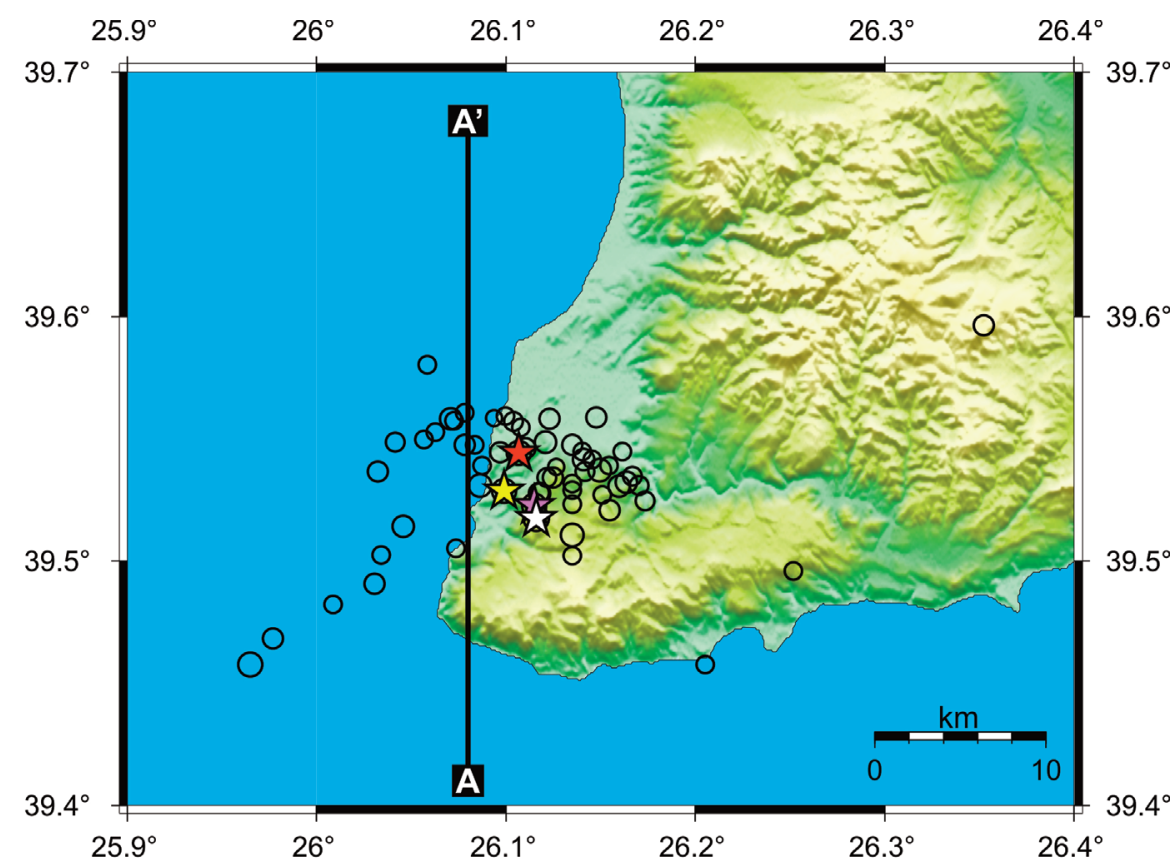

Distance $(\mathrm{km})$

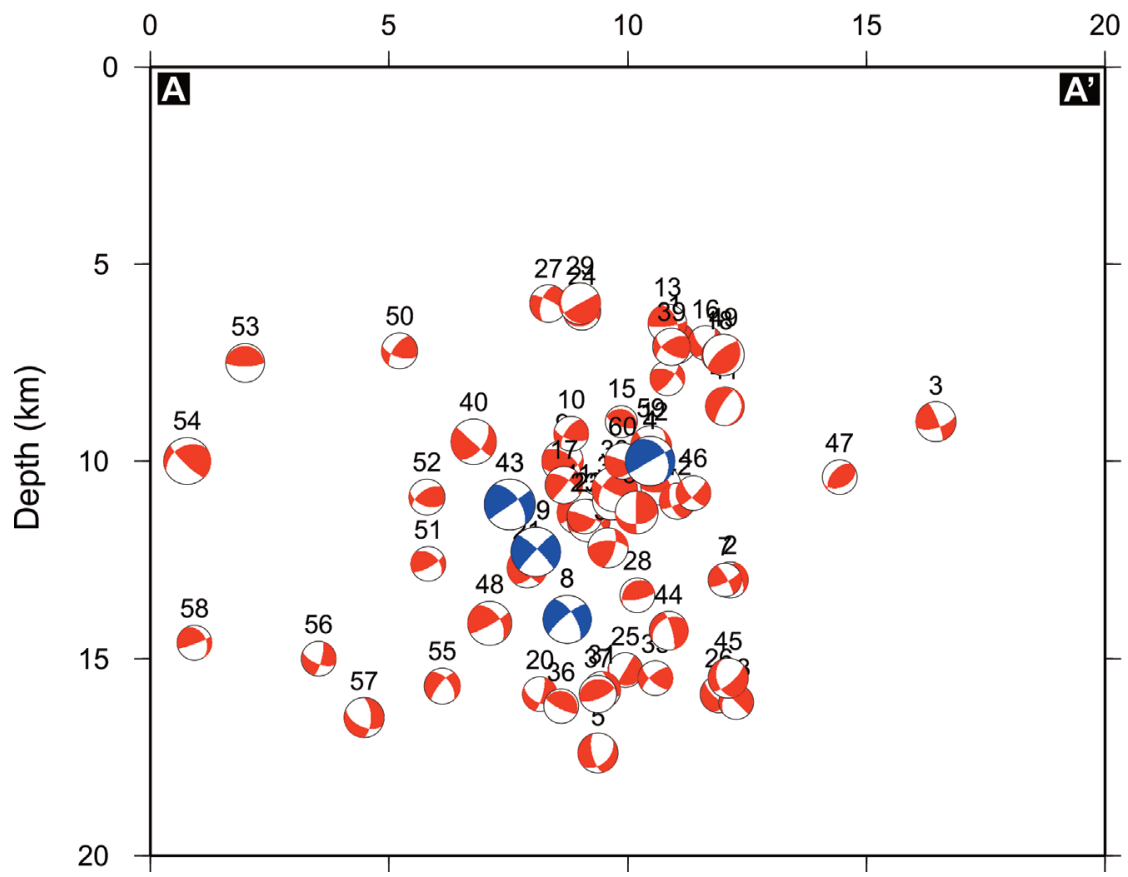

Figure 6. Epicenter distribution of the selected aftershocks $\left(M_{w} \geq 3.5\right)$ in the region off-shore and on-shore southwestern Biga Peninsula along Ayvacık EQ area. A-A' is the depth cross-section profile. The cross-section is N-S direction perpendicular to the strike of the fault rupture. The aftershock sequence lies in the depth range from 5 to $17 \mathrm{~km}$ for $M_{w} \geq 3.5$ events. Orientation of aftershocks trends NW-SE direction. The main aftershock cluster is clearly depicted in the $\sim 12 \mathrm{~km}$ width vertical zone of the cross-section. 6 February 2017 03:51 Mw 5.2, 6 February 2017 10:58 Mw 5.1, 7 February 2017 02:24 Mw 5.2, 12 February 2017 13:48 Mw 5.3. 


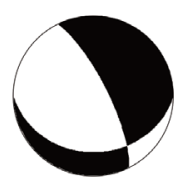

(strike, dip, rake $)=(333,76,-63)$

$($ lon, lat, depth $)=\left(26.1068^{\circ}, 39.5443^{\circ}, 10 \mathrm{~km}\right)$

$M_{0}=7.62 e+16 \mathrm{Nm}, M_{w}=5.2$

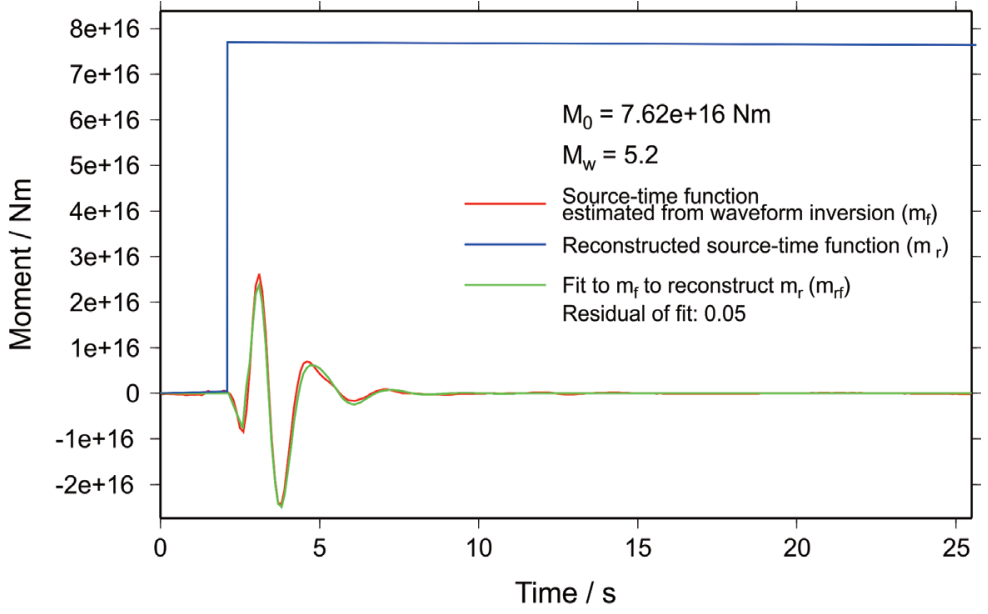

BOZC EW
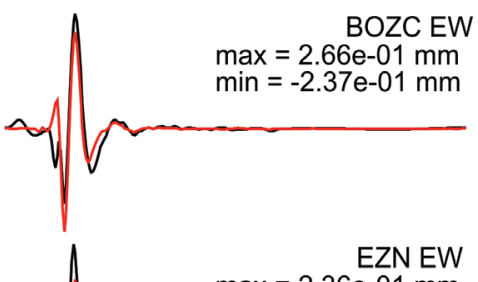

$\max =2.36 \mathrm{e}-01 \mathrm{~mm}$

$\min =-2.32 \mathrm{e}-01 \mathrm{~mm}$

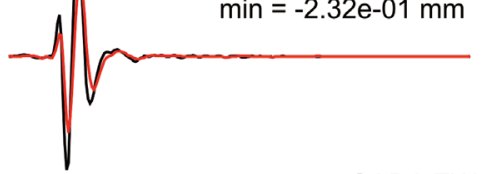

GADA EW

$\max =1.17 \mathrm{e}-01 \mathrm{~mm}$

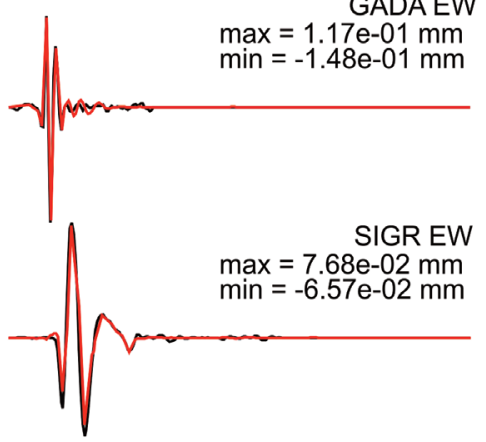

Obs.

Syn.

Residual $=0.05$

Frequency range

$0.02-0.05(\mathrm{~Hz})$
BOZC NS

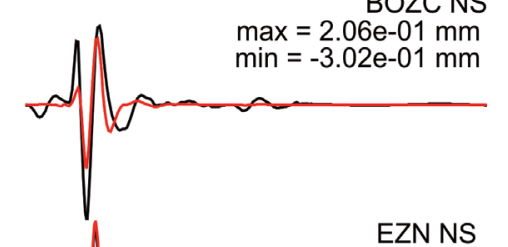

$\max =3.50 \mathrm{e}-01 \mathrm{~mm}$ $\min =-3.53 e-01 \mathrm{~mm}$

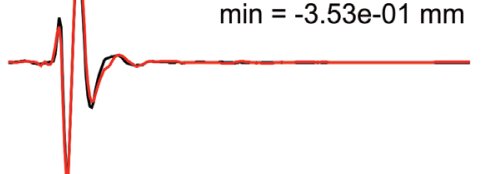

GADA NS
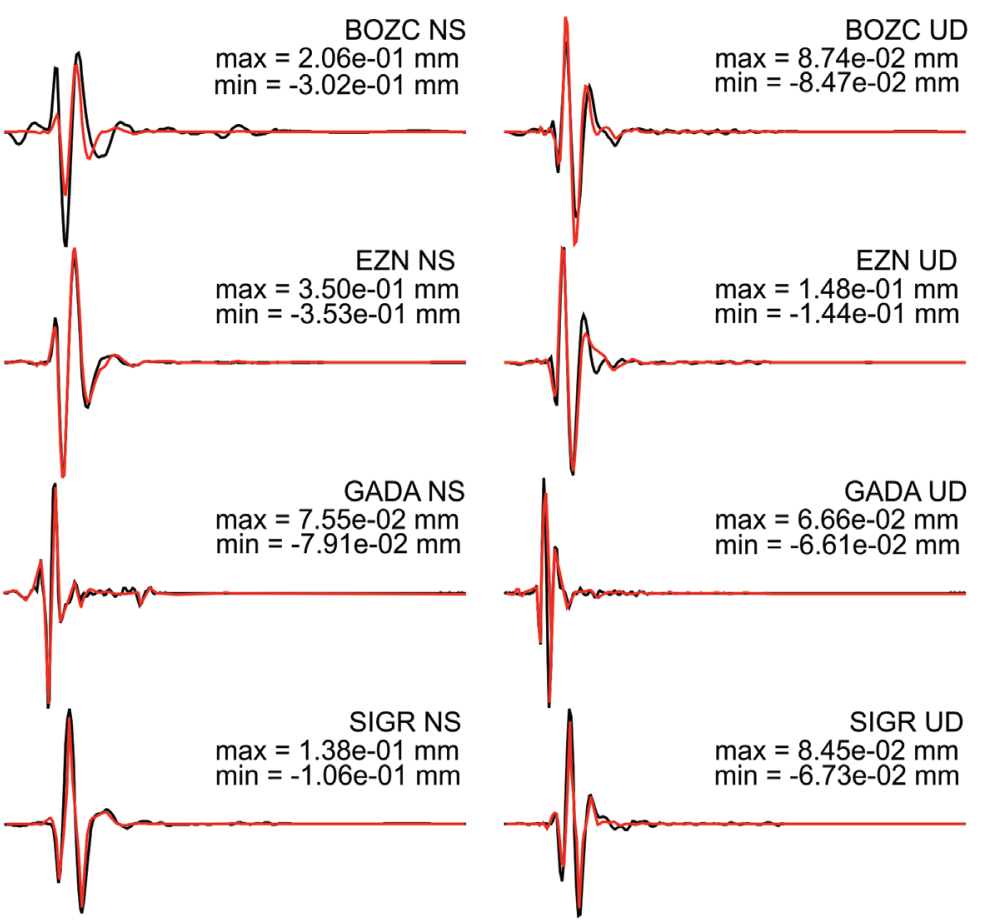

EZN UD

$\max =1.48 \mathrm{e}-01 \mathrm{~mm}$ $\min =-1.44 \mathrm{e}-01 \mathrm{~mm}$
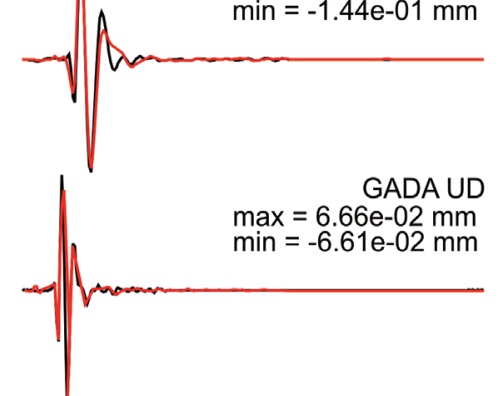

GADA UD

$\max =6.66 \mathrm{e}-02 \mathrm{~mm}$ $\min =-6.61 \mathrm{e}-02 \mathrm{~mm}$

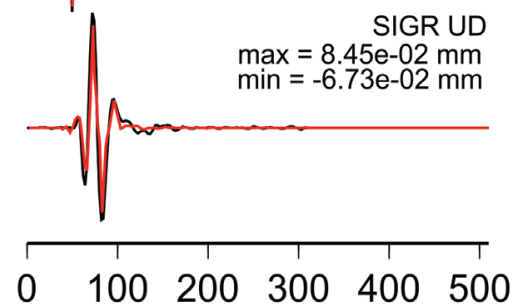

Time/s

Figure 7. Estimated focal mechanism and source parameters of the 6 February 2017 03:51 $M_{w} 5.2$ event. Waveform fittings obtained from the waveform inversion. Black and red lines represent the observed and synthesized seismograms, respectively. The station code and component of motions are indicated at the upper right of each seismogram. Maximum and minimum displacements are shown at the upper right of each seismogram. Upper right side, the moment functions ( $m^{f}$, red line; input moment function) and the functions $m_{d}^{f}$ (green line; bandpass filtered moment function) obtained from the waveform inversion of the 6 February 03:51 mainshock. Blue line represents the deconvolved form of the moment function $\left(m_{d}\right)$. 
The 2017 Ayvacik Earthquake Sequence

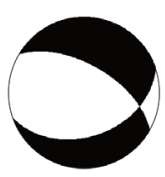

(strike, dip, rake $)=(300,60,-60)$

$($ lon, lat, depth $)=\left(26.0990^{\circ}, 39.5287^{\circ}, 14 \mathrm{~km}\right)$

$\mathrm{M}_{0}=5.7 \mathrm{e}+16 \mathrm{Nm}, \mathrm{M}_{\mathrm{w}}=5.1$
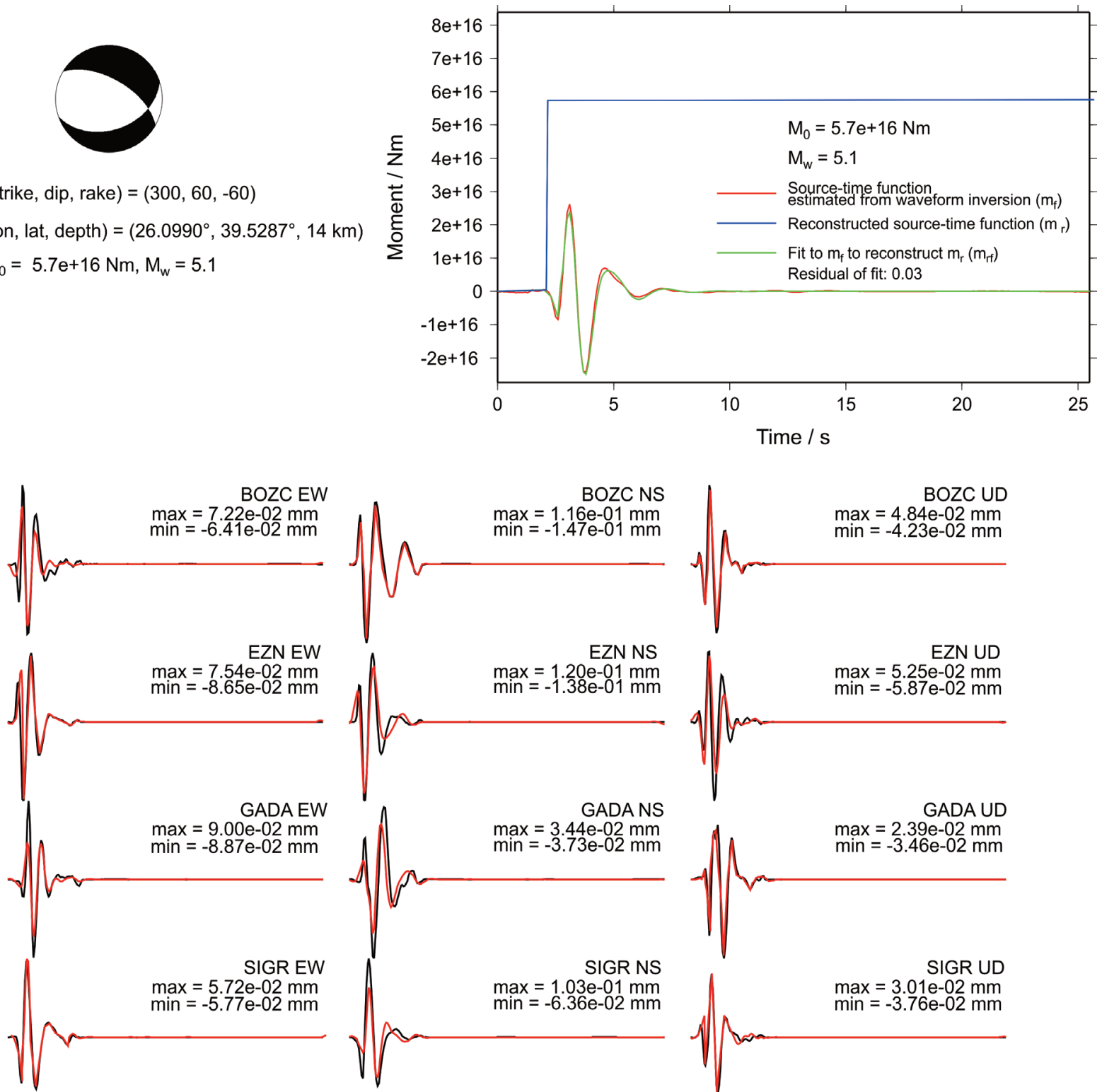

$\max =5.25 \mathrm{e}-02 \mathrm{~mm}$
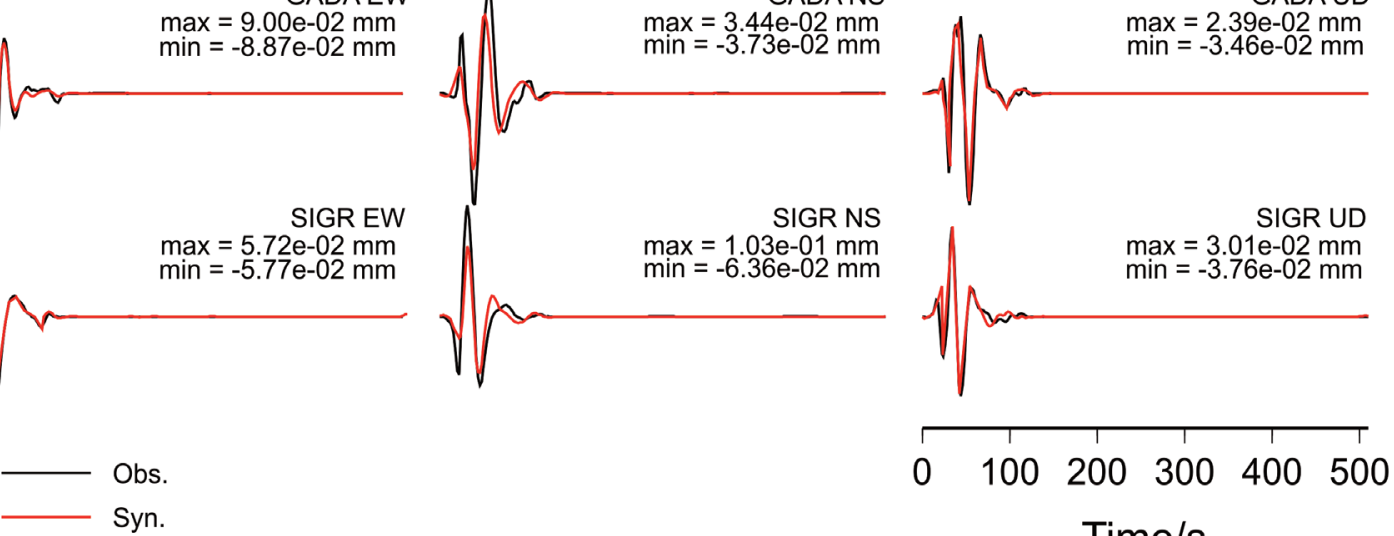

Syn.

Residual $=0.03$

Time/s

Frequency range

$0.02-0.05(\mathrm{~Hz})$

Figure 8. Estimated focal mechanism and source parameters of the 6 February 2017 10:58 $M_{w} 5.1$ event. Same as Figure 6. 


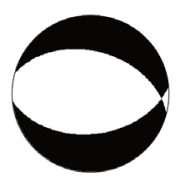

(strike, dip, rake $)=(285,45,-75)$

$($ Ion, lat, depth $)=\left(26.1148^{\circ}, 39.5227^{\circ}, 12.3 \mathrm{~km}\right)$

$M_{0}=6.7 e+16 ~ N m, M_{w}=5.2$

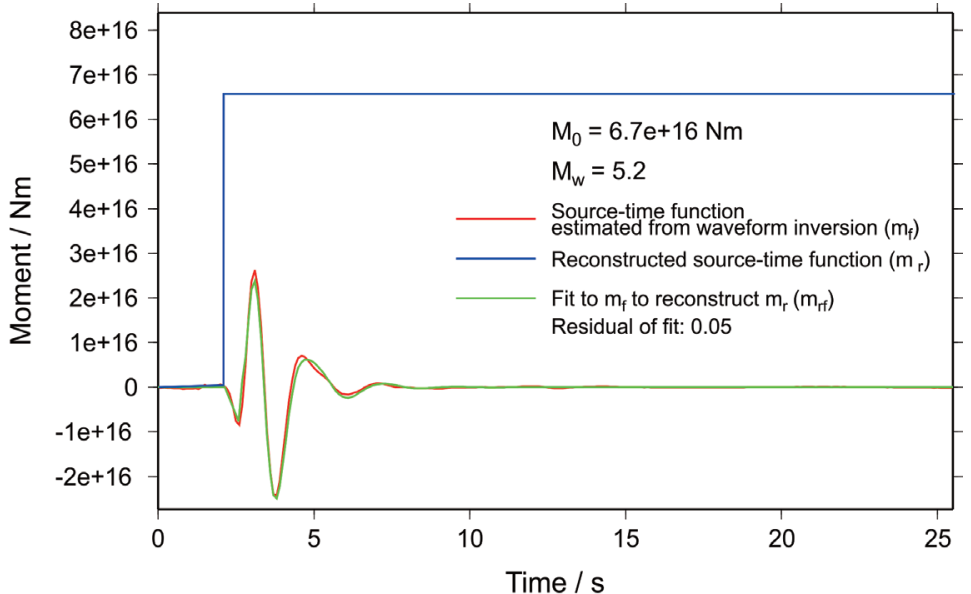

BOZC EW

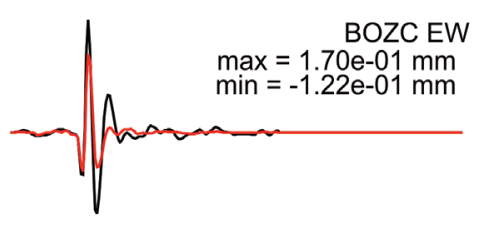

EZN EW

$\max =1.22 \mathrm{e}-01 \mathrm{~mm}$

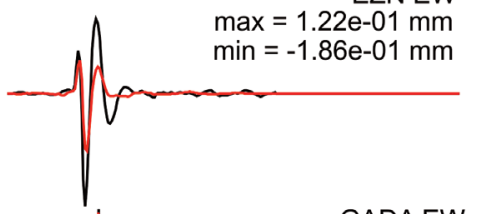

GADA EW

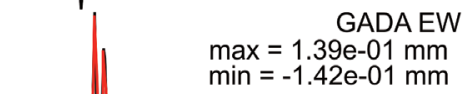
$\min =-1.42 \mathrm{e}-01 \mathrm{~mm}$

SIGR EW $\max =1.57 \mathrm{e}-01 \mathrm{~mm}$ $\min =-8.37 \mathrm{e}-02 \mathrm{~mm}$
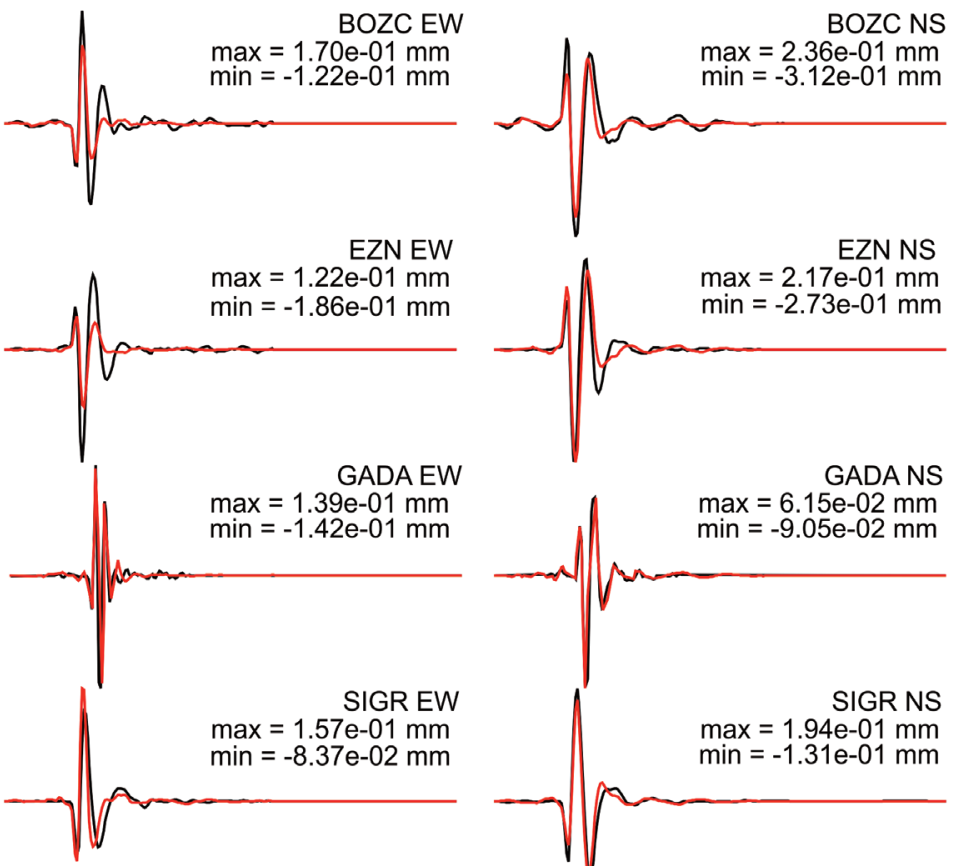

GADA NS

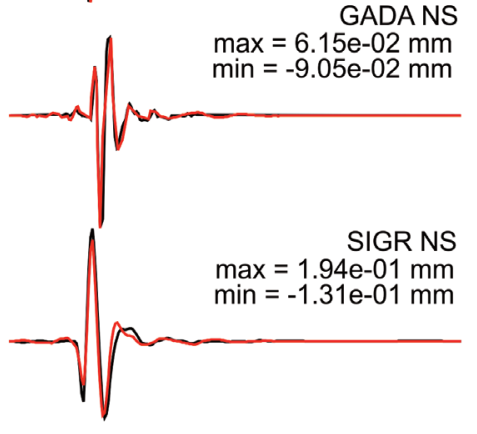

Obs.

Syn.

Residual $=0.05$
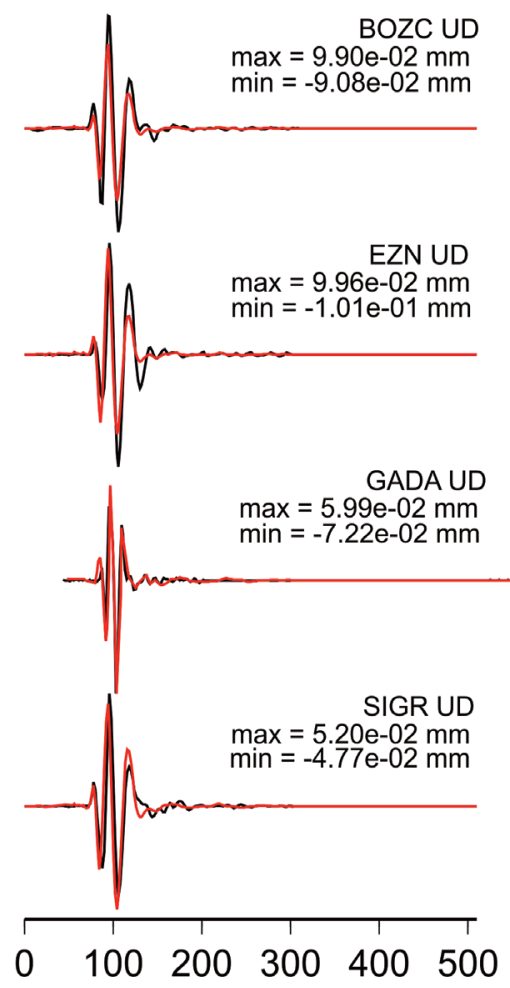

Time/s

Frequency range $0.02-0.05(\mathrm{~Hz})$

Figure 9. Estimated focal mechanism and source parameters of the 7 February 2017 02:24 $M_{w} 5.2$ event. Same as Figure 6. 
The 2017 Ayvacik Earthquake Sequence

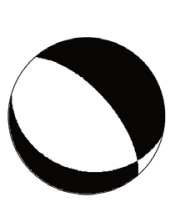

(strike, dip, rake $)=(310,60,-70)$

(lon, lat, depth $)=\left(26.1160^{\circ}, 39.5177^{\circ}, 11.1 \mathrm{~km}\right)$ $M_{0}=1.16 e+17 \mathrm{Nm}, M_{w}=5.3$

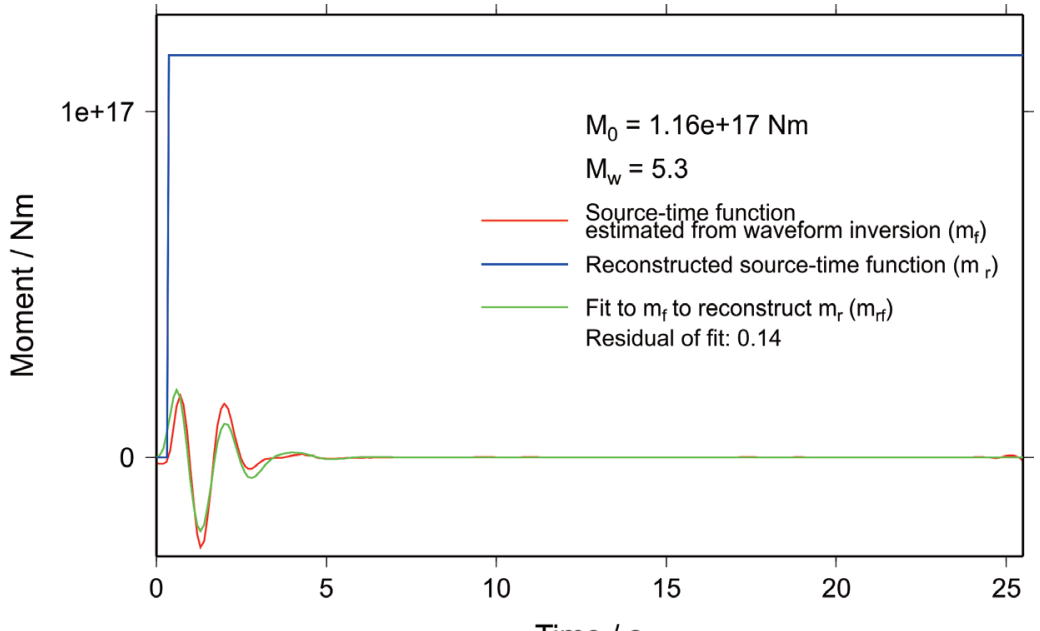

BOZC EW $\max =1.24 \mathrm{e}-01 \mathrm{~mm}$ $\min =-9.63 e-02 \mathrm{~mm}$

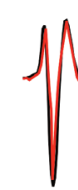

EZN EW
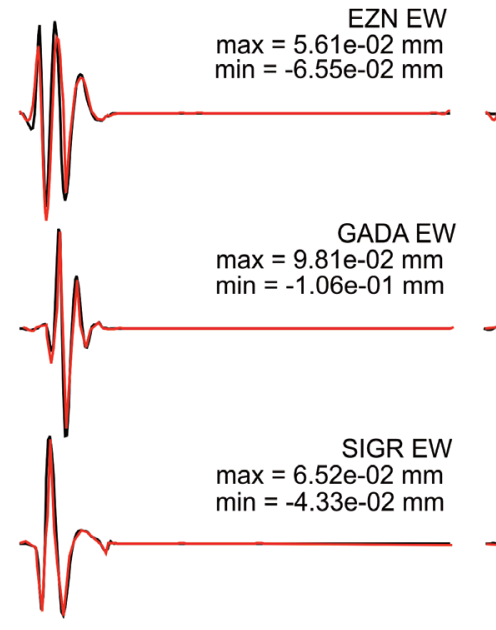

Obs

Syn

Residual $=0.05$

Frequency range $0.02-0.05(\mathrm{~Hz})$
BOZC NS $\max =1.23 \mathrm{e}-01 \mathrm{~mm}$ $\min =-2.26 e-01 \mathrm{~mm}$

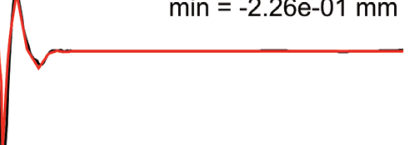

Time / s

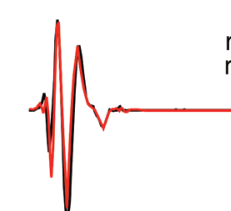

$\begin{aligned} & \text { BOZC UD } \\ & \max =3.72 \mathrm{e}-02 \mathrm{~mm}\end{aligned}$ $\min =-4.42 \mathrm{e}-02 \mathrm{~mm}$
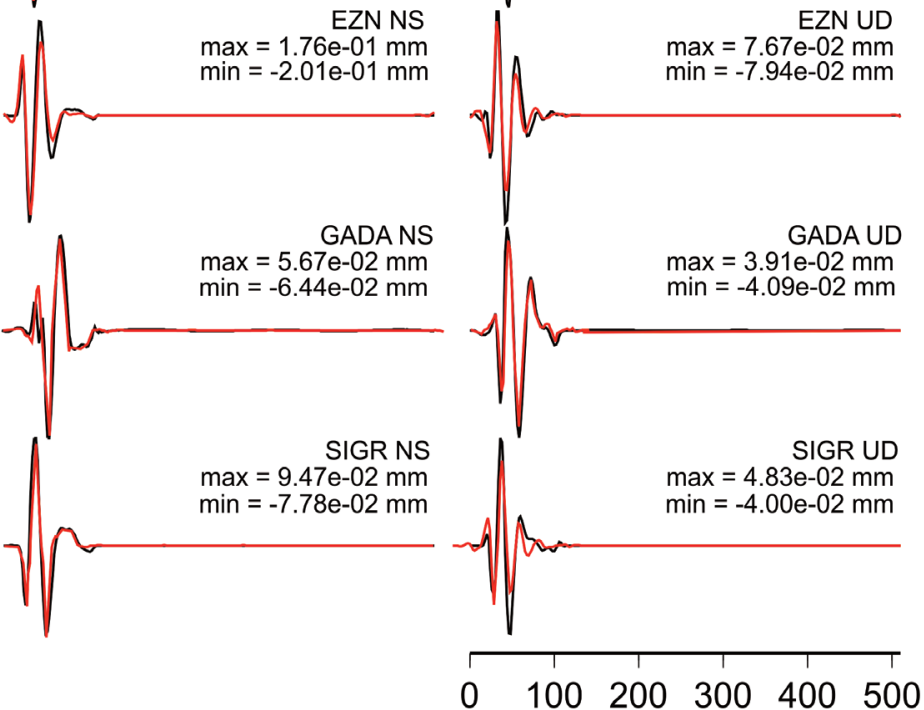

Time/s

Figure 10. Estimated focal mechanism and source parameters of the 12 February 2017 13:48 $M_{w} 5.3$ event. Same as Figure 6. 


\section{Ethem Görgün et al.}

\subsection{Analysis of stress tensors}

The results of the stress tensor inversion are presented in Figure 11. The measure of the misfit values is evaluated by the areas of $95 \%$ confidence limit (see Figure 11). Stress tensor inversion of the Ayvacik EQ aftershocks reveals a substantial high level of uniform stress for the entire catalog $\left(\bar{\beta}=23^{\circ}\right)$ according to Michael (1991). The maximum principal stress, $\sigma_{1}$, trends $\mathrm{N} 30^{\circ} \mathrm{W}$ with a plunge of $4^{\circ}$ and the minimum principal stress, $\sigma_{3}$, trends $\mathrm{N} 182^{\circ} \mathrm{E}$ with a plunge of $84^{\circ}$ (Figure 11). The resulting stress tensor corresponds to a transtensional stress regime $(R=0.75)$. The orientation of the maximum horizontal compressional stress $\left(\mathrm{S}_{\mathrm{H}}\right)$ is WNW-ESE and normal faulting stress regime is found for the study region.

Low variance (0.10) indicates a good fit of homogeneous stress tensor to the observed focal mechanism, and shows low heterogeneity of the stress field [Michael et al., 1990; Lu et al., 1997; Wiemer et al., 2002; Görgün et al., 2010]. The alignment of $\sigma_{1}$ is NW-SE. Deformation regimes obtained from the stress tensor inversion indicate the predominant normal faulting regime with strike-slip component in the mainshock area (Figure 10). Wiemer et al. [2002] concluded that a low degree of heterogeneity in stress field (variance $<0.2$ ) indicates uniformity. There is no significant variance in stress tensor orientations (variance $<0.2$ ). Thus, to first order, the Ayvacık EQ region is characterized by a homogeneous intraplate stress field.

a) Principal stress and $P / T$ axes

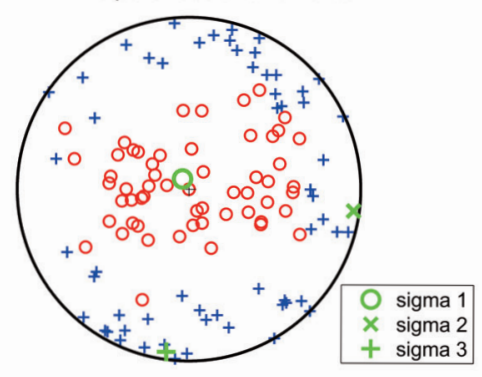

b) Confidence of principal stress axes

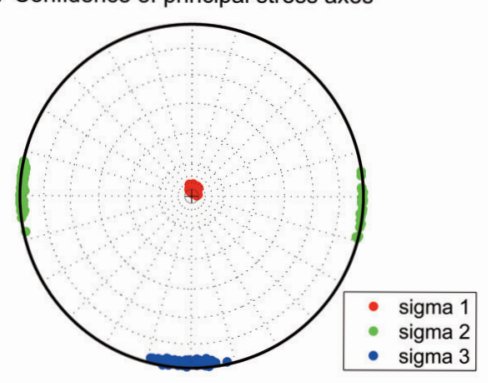

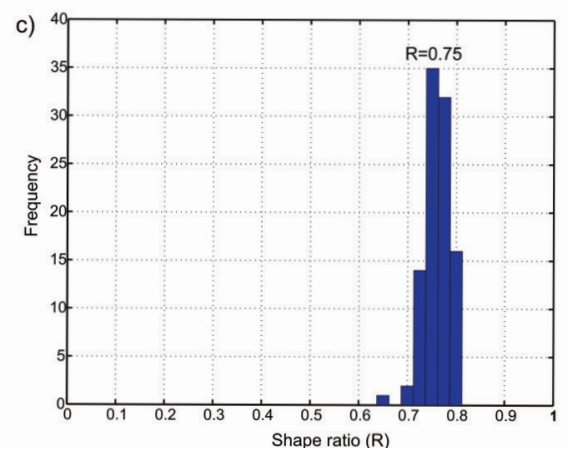

Figure 11. a) P/T-axes for the events in Fig. 4 (Table 2) with retrieved principal stress directions (green signs on the figure). The $P$ and $T$ axes are marked by red circles and blue plus signs, respectively $\mathbf{b}$ ) Confidence limits of the principal stress directions retrieved by the iterative method [Vavryčuk, 2014]. Red, green and blue colours correspond to the $\sigma_{1}, \sigma_{2}$ and $\sigma_{3}$ stress directions, respectively. The contours around the best model define the $95 \%$ confidence region of each stress axis. c) Histograms of the stress ratio $(R)$ which is found to be 0.75 . This value indicates that the study region is described by transtensional stress regime.

\subsection{Calculation of the Coulomb stress change}

The static Coulomb stress change caused by a mainshock has been widely applied to assess areas of subsequent off-fault aftershocks [Reasenberg and Simpson, 1992; Toda et al., 2008; 2011a]. The Coulomb stress change is defined as $\Delta C F F=\Delta \tau+\mu \Delta \sigma$, where $\tau$ is the shear stress on the fault (positive in the inferred direction of slip), $\sigma$ is the normal stress (positive for fault-normal tension) and $\mu$ is the apparent friction coefficient. Failure is promoted if $\triangle C F F$ is positive and inhibited if negative; both increased shear and unclamping of faults are taken to promote failure, with the influence of unclamping controlled by fault friction [Toda et al., 2011a]. After the occurrence of an earthquake, the areas with positive values of $\triangle C F F$ are loaded with stress. To resolve the Coulomb stress change on a 'receiver fault' requires a source model of the earthquake fault slip, as well as the geometry and slip direction on the receiver [Toda et al., 2011a]. We can find the receiver faults at every point in the Coulomb stress increase that maximize the earthquake stress change and the tectonic stress [King et al., 1994], termed the 'optimally-oriented' Coulomb stress change [Toda et al., 2011a].

The source parameters deduced from waveform modelling are used to calculate the Coulomb stress change for the 4 largest events (Table 2). The stress tensor principal axes $\left(\sigma_{1}, \sigma_{2}\right.$ and $\left.\sigma_{3}\right)$ are also added to compute the spatial 

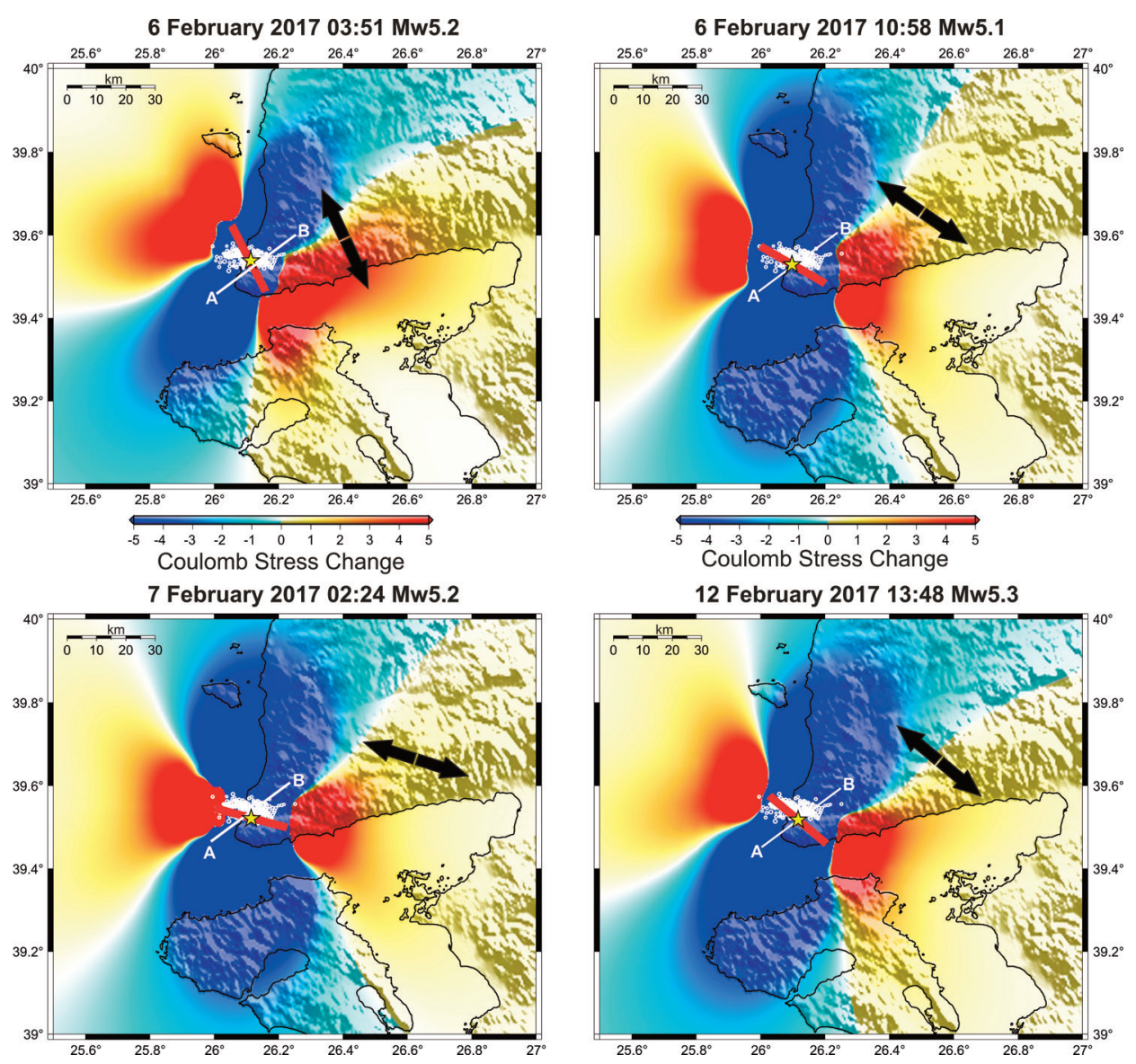

Figure 12. Coulomb stress change, taking into account the four main events $M_{w}>5.0$ for 2017 Ayvacık EQ sequence. Color palette of Coulomb stress values is leveled in the range $-5 /+5$ bar. Red color represents positive stress changes, while blue negative. Yellow star represents the 6 February $2018 M_{w} 5.2$ mainshock. Red line displays the coseismic rupture based on the calculated strike, dip and rake angles of focal mechanisms. We define the size of the rupture with respect to the magnitude of the earthquakes. White circles represent $M_{l} \geq 3.0$ aftershocks of the Ayvacık seismic activity from 6 February to 28 February 2018. Black arrows display the maximum horizontal compressive stress $\left(S_{H}\right)$ from the stress tensor inversion.

distribution of the Coulomb stress change (Figure 12). The stress changes are resolved at $10 \mathrm{~km}$ depth based on the estimated geometry of major active faults. Increased shear stress in the rake direction and unclamping on surrounding "receiver" faults are interpreted to promote failure [Toda et al., 2008]. We resolve the shear and normal (clamping/unclamping) components of the stress change on a 2D grid of points or on specified "receiver" fault planes. We make a regular grid with receiver faults every $5 \mathrm{~km}$. Receiver faults are planes with a specified strike, dip, and rake, on which the stresses imparted by the source faults are resolved; we call these "specified faults" in the Coulomb stress calculation. The shear stress increase or decrease is dependent on the position, geometry, and slip of the source fault and on the position and geometry of the receiver fault, including its rake. The normal stress change (clamping or unclamping) is independent of the receiver fault rake [Toda et al., 2011b]. The Coulomb 3.3 software (www.coulombstress.org) is used to project normal faulting with significant strike-slip component mechanism at a depth of $10 \mathrm{~km}$ with a strike/dip/rake of $333^{\circ} / 76^{\circ} /-63^{\circ}$ and a friction coefficient $\mu=0.4$ in an elastic half space with uniform isotropic elastic properties[Lin and Stein, 2004; Toda et al., 2005; 2008; 2011a].

The spatial distributions of the Coulomb stress change due to the occurrence of the 2017 Ayvacık EQ sequence $M_{w}$ $>5.0$ events are presented in Figure 12. We analyze four mainshocks (the same as we described in the preceding section) with $\mathrm{M}_{\mathrm{w}}$ bigger than 5.0. According to our analysis, four mainshocks indicate similar Coulomb stress failure patterns about Ayvacık EQ sequence. Stress increase regions brought closer to failure are represented by the red lobes. Positive Coulomb stress change is observed in NW-SE direction of the rupture zone. The eastern and western ends of 

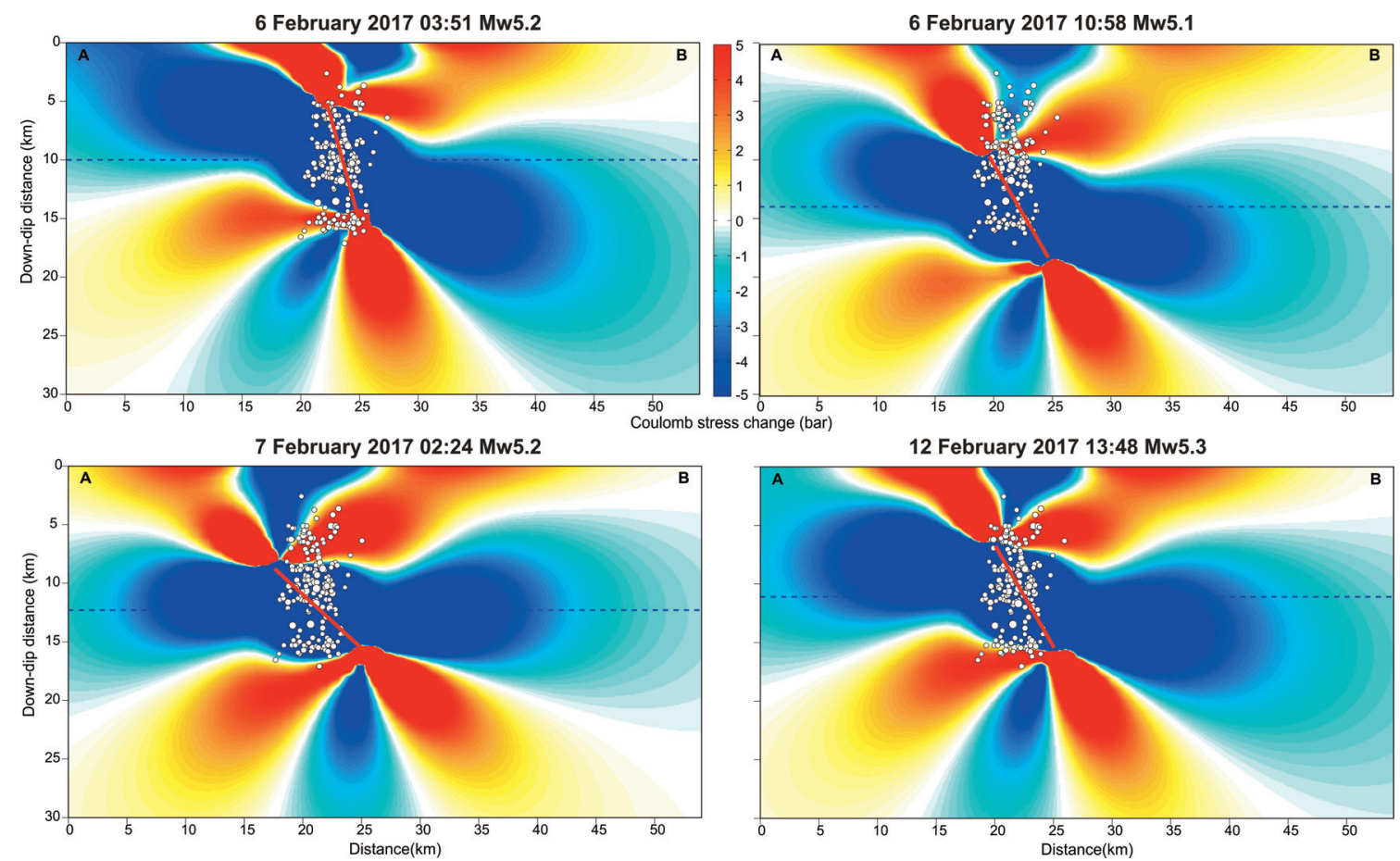

Figure 13. Cross-sections of Coulomb stress distribution for four mainshocks. Profiles are shown in Fig. 10. Red line donates coseismic ruptures of the mainshocks according to fault geometry based on this study (Table 2). White circles represent earthquake hypocenters. The size of the solid white circles is proportional to magnitude.

the Ayvacık EQ sequence ruptures are brought to 3-5 bars closer to failure. Stress changes of $\geq 1$ bars are generally observed to influence seismicity rates [King et al., 1994]. Prior to February $6 M_{w} 5.2$ mainshock, there is another moderate event occurred on 14 January 2017 with a $\mathrm{M}_{\mathrm{w}}$ 4.5. This event has identical focal mechanism with four $\mathrm{Mw}>$ 5.0 earthquakes. $14^{\text {th }}$ January event is the foreshock just before occurring February 6 moderate size earthquakes. This event is important for Coulomb stress distribution since $\mathrm{M}_{\mathrm{w}}>5.0$ earthquakes are quite close to each other.

To further compare the Coulomb stress change and Ayvacık EQ aftershocks, a cross-section is presented in Figure 13 along the route A-B (perpendicular to the fault geometry) shown in Figure 12. Most of Ayvacik EQ aftershocks $\left(\mathrm{M}_{1} \geq 3.0\right)$ lie in the region of $<-1$ bar Coulomb stress decrease (Figure 12 and 13). Nevertheless, some of aftershocks (especially 6 February 03:51 and 7 February 02:24 events, Figure 13, A-B profile) $\mathrm{M}_{1} \geq 3.0$ lie above the fault plane, where the Coulomb stress is calculated to have increased.

\section{Discussion and conclusions}

The spatio-temporal distribution and source characteristics of the February 2017 Ayvacik EQ sequence are investigated. The distribution of relocated hypocenters and focal mechanisms clearly indicate the activation of a $\mathrm{N} 182^{\circ} \mathrm{E}$ trending normal faulting system. The stress tensor inversion results reveal a predominant normal stress regime with an almost horizontal (E-W, for entire 60 events) and NW-SE (according to four $\mathrm{M}_{\mathrm{w}}>5.0$ events) orientation the maximum horizontal compressional stress $\left(\mathrm{S}_{\mathrm{H}}\right)$. The entire study region is rather homogeneous according to the stress tensor inversion results (variance $<0.2$, Figure 11). The relative stress magnitude $(R)$ is estimated to be 0.75 (transtensional stress regime) for the Ayvacı EQ region. Therefore, to first order, the Ayvacık EQ region is characterized by a homogeneous intraplate stress field as far as the orientation of stress is concerned (Figure 11).

High-resolution aftershock locations reveal a complex pattern of the hypocenter distribution with the activation of ten different fault segments (Figure 3, defined by red and black dashed-lines). The westernmost segment (blue, see Figure 3) is related to a fault plane trending NE-SW and dipping towards SSW, while the eastern segments are 


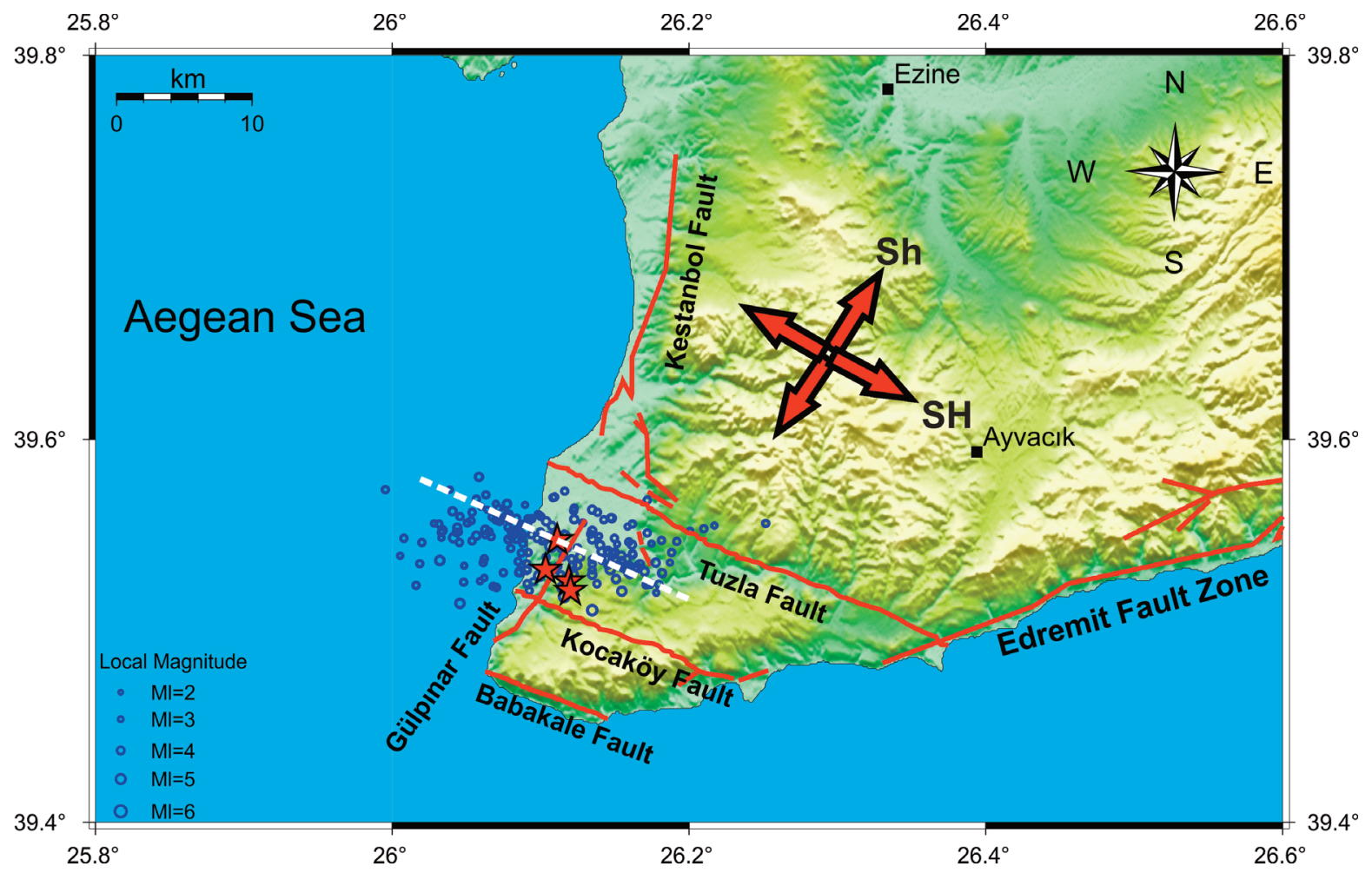

Figure 14. Topographic map of Ayvacık EQ sequences after the 6 February $2017 M_{w} 5.2$ 03:51 mainshock. Blue circles indicate aftershock epicenters following the mainshock. Red lines represent the active fault segments in vicinity of the EQ swarm region [Emre et al., 2013; Özden et al., 2018]. White dashed line shows the 2017 Ayvacık EQ rupture. Red arrows depict maximum $\left(S_{H}\right)$ and minimum $\left(S_{h}\right)$ horizontal compressive stresses.

related to a fault plane trending E-W and dipping towards almost horizontal and SE. There are several smaller-scale transtensional structures along faults in off-shore Biga Peninsula where close to the 2017 Ayvacık EQ sequence occurred. According to the seismic reflection data from Boztepe-Güney et al. [2001] and Yaltırak et al. [2012], offshore Biga Peninsula is active, because it exhibits sea-bottom scarps and cuts across the western prolongation of the NAFZ. The dimensions of the activated region do not remain constant during the evolution of the seismic sequence, even though the seismicity gradually decreased. To explain the observed extended spatial distribution, the double-difference relocation algorithm is performed, using the absolute locations as an input calculated in the framework of this study. The analysis reveals prominent eastern and western segments of the activated seismogenic region. The westernmost cluster (blue, Figure 3) has relatively small magnitude events with $\mathrm{M}_{1} \leq 3.5$. The eastern segments (orange and purple, see Figure 3), where the mainshock occurred, indicates the seismicity along the east direction and to cause the observed elongation of the activated region.

Five moderate size earthquakes ( $4.5 \leq \mathrm{M}_{\mathrm{w}} \leq 5.4$ ) have been observed along the 2017 Ayvacık EQ region since 1985 (Figure 1b). The largest event $\left(\mathrm{M}_{\mathrm{W}}=5.4\right)$ occurred in 1989 southwest of the 2017 Ayvacik EQ. It has similar mechanism with the 2017 Ayvacık sequence but different strike direction. The 2017 Ayvacık EQ rupture zone covers the $2007 \mathrm{M}_{\mathrm{w}} 4.5 \mathrm{EQ}$ mainshock rupture (Figure 1b). In a broad context, the Aegean Sea region (including west of Anatolia) is a domain characterized by diffuse deformation (widespread plate boundary deformation between Eurasia and Anatolian plates), which is affected by both the Aegean Sea back-arc extension, approximately N-S, and by the shear transferred from east or north, due to the movement of the North Anatolian Fault Zone [Nyst and Thatcher, 2004; Le Pichon and Kreemer, 2010; Reilinger et al., 2010]. BP faults located in well-defined extensional basins are controlled by NW-SE trending normal and NE-SW trending strike-slip movements. These five events are example of a NE-SW trending strike-slip faulting with normal component (Figure 1b). This type of strike-slip faulting is predominantly observed in the northern Aegean Sea region and further to the south (Figure 1). The sequence investigated here is a typical example of pure NW-SE trending normal motions. 


\section{Ethem Görgün et al.}

During the 2017 seismic sequence in the Ayvacık area, an epicenter migration is also observed for the 4 larger magnitude earthquakes. The spatio-temporal distribution of Ayvacık seismic activity exhibits that the master event of the 6 February 03:51 is followed by three other equivalent earthquakes within the rupture zone (Figure 14). This migration appears to follow a direction of progressively increasing stress, from the north-western part of the EQ cluster, towards the south-eastern part (Figure 3). In agreement with these results is also the Coulomb stress redistribution due to the occurrence of the first two events that indicate a maximum stress transfer from the northwest, towards the epicenters of the following two large shocks that occurred subsequently in the southeastern part of the rupture zone.

In this study, all aftershocks are shallower than $25 \mathrm{~km}$. Furthermore, similar findings were published by Akyol et al. [2006]. Accordingly, it can be speculated that the thickness of brittle seismogenic crust in Biga Peninsula area is about $25 \mathrm{~km}$. This aftershock study also indicates that the majority of aftershocks occur in the crust shallower than $20 \mathrm{~km}$ with the exception of few events about $23 \mathrm{~km}$ (in the main cluster, profiles B-B' and C-C').

Figure 14 represents aftershock epicenters in the vicinity of February $2017 \mathrm{EQ}$ swarm area. Four events $\mathrm{M}_{\mathrm{w}}>5.0$ are located on Gülpınar Fault. Their location shows that the four main events directly occurred along the Gülpınar Fault and then the aftershock activity spreads out NW-SE direction. This rupture zone is indicated by the white dashed line. This can be interpreted as the rupture zone is parallel to the Tuzla Fault. This zone is also located between the Tuzla and Kocaköy Faults. We state that this rupture zone that belongs to February 2017 EQ swarm activity, is an independent and unknown segment from the existing fault lines. Kandilli Observatory and Earthquake Research Institute (KOERI) intensity data distribution is correlated with this new fault segment in the Ayvacik EQ region. According to KOERI intensity map, event locations along this fault zone are related to high intensity values (www.koeri.boun.edu.tr). This new segment has not only on-shore but also off-shore parts. Almost half of the EQ epicenters are located along the off-shore sections of this rupture zone (Figure 14). Livaoğlu et al. [2018] also indicated a damage distribution map related to the Ayvacı EQ sequences. According to their findings, damage ratio of structures is higher in villages close to epicenters along the new segment that found in this study.

To conclude, the Ayvacık EQ sequence that occurred in the north of Aegean Sea off-shore Biga Peninsula is clearly indicating that active NE-SW trending $\left(\sigma_{3}\right)$ normal faulting systems are wide-spread in the Aegean region. These tectonic structures impose a threat to the nearby districts and provinces along the northern Aegean Sea region and western Anatolia. Additionally, the Ayvacık EQ sequence helps to improve the knowledge of the offshore Biga Peninsula and Edremit Gulf seismotectonics and Coulomb stress change. It also may carry important information on the nature of future earthquakes along the Biga Peninsula and near tectonic structures in Mytilini and NW Anatolia.

Acknowledgements. We thank all members of National Earthquake Monitoring Center (NEMC) at Kandilli Observatory and Earthquake Research Institute (KOERI), Disaster and Emergency Management Presidency Earthquake Department (AFAD) and the Aristotle University of Thessaloniki (AUTH) for providing the continuous seismological data used in this study. We are also grateful to Dr. Masaru Nakano for providing the waveform inversion code. All figures are generated by Generic Mapping Tools (GMT) code developed by Wessel and Smith [1998].

\section{References}

Akyol, N., L. Zhu, B. J. Mitchell, H. Sözbilir, and K. Kekovalı (2006). Crustal structure and local seismicity in western Anatolia, Geophys. J. Int., 166, 1259-1269.

Ateş, A., A. Büyüksaraç, F. Bilim, Ö., Bektaş, Ç., Şendur, G. Komanovalı (2009). Spatial correlation of the aeromagnetic anomalies and seismogenic faults in the Marmara region, NW Turkey, Tectonophysics, 478, 135-142.

Aydoğan, D., (2007). Processing the Bouguer anomaly map of Biga and the surrounding area by the cellular neural network: application to the southwestern Marmara region, Earth Planets Space, 59, 201-208.

Barka, A.A., R. Reilinger, F. Şaroğlu, and A. M. C. Şengör (1997). The eastern Isparta angle, its importance in neotectonics of the eastern Mediterranean region, IESCA-1995 Proceedings, 1, 3-17.

Bird, P., (2003). An updated digital model of plate boundaries, Geochem. Geophys., 4, 1027, doi:10.1029/2001GC000252. 
Bohnhoff, M., P. Martínez-Garzón, F. Bulut, E. Stierle, and Y. Ben-Zion (2016). Maximum earthquake magnitudes along different sections of the North Anatolian fault zone, Tectonophysics 674, 147 -165.

Bott, M.H.P. (1959). The mechanics of oblique slip faulting, Geological Magazine, 96, 109-117.

Bouchon M. (1979). Discrete wave number representation of elastic wave fields in three-space dimensions, J. Geophys. Res. 84, 3609-3614.

Boztepe-Güney, A., Y. Yılmaz, E. Demirbağ, B. Ecevitoğlu, S. Arzuman, and I. Kuşçu (2001). Reflection seismic study across the continental shelf of Baba Burnu promontory of Biga Peninsula, northwest Turkey, Marine Geology, $176,75-85$.

Emre, Ö., T. Y. Duman, S. Özalp, H. Elmacı, Ş. Olgun, and F. Şaroğlu (2013). 1:250.000 Scale Active Fault Map of Turkey, General Directorate Mineral Research and Exploration, Ankara, Turkey.

Erdik, M., M. Demircioglu, K. Sesetyan, E. Durukal, and B. Siyahi (2004). Earthquake hazard in Marmara Region, Turkey, Soil Dynamics and Earthquake Engineering 24, 605-631.

Fichtner, A., E. Saygin, T. Taymaz, P. Cupillard, Y. Capdevillee, and J. Trampert (2013). The Deep Structure of the North Anatolian Fault Zone, Earth Planet. Sci. Lett., 373, 109-117, doi:10.1016/j.epsl.2013.04.027.

Ganas, A., P. Kourkouli, P. Briole, A. Moshou, P. Elias, and I. Parcharidis (2018). Coseismic displacements from moderate-size earthquakes mapped by Sentinel-1 differential interferometry: The case of February 2017 Gulpinar Earthquake Sequence (Biga Peninsula, Turkey), Remote Sensing, 10, 1089.

Gephart, J.W. and D. W. Forsyth (1984). An Improved Method for Determining the Regional Stress Tensor Using Earthquake Focal Mechanism Data: Application to the San Fernando Earthquake Sequence, J. Geophys. Res., 89, B11, 9305-9320.

Görgün, E., M. Bohnhoff, F. Bulut, G. Dresen (2010). Seismotectonic settings of the Karadere-Düzce branch of the North Anatolian Fault Zone between the 1999 Izmit and Düzce ruptures from analysis of Izmit aftershock focal mechanisms, Tectonophysics, 482, 170-181.

Gürer, Ö.F., E. Sangu, and M. Özburan (2006). Neotectonics of the SW Marmara region, NW Anatolia, Turkey, Geol. Mag. 143 (2), 229-241.

Hardebeck, J.L., and E. Hauksson, (2001). Stress orientations obtained from earthquake focal mechanisms: what are appropriate uncertainty estimates?, B. Seismol. Soc. Am., 97, 826-842.

Kalafat, D., K. Kekovalı, Y. Güneş, M. Yılmazer, M. Kara, P. Deniz, and M. Berberoğlu (2009). A catalogue of source parameters of moderate and strong earthquakes for Turkey and its surrounding area (1938-2008), Boğaziçi University Press, Kandilli Observatory and Earthquake Research Institute, Istanbul.

King, G.C.P., R. S. Stein, and J. Lin (1994). Static stress changes and the triggering of earthquakes, B. Seismol. Soc. Am.,, 84, 935-953.

Kind, R., T. Eken, F. Tilmann, F. Sodoudi, T. Taymaz, F. Bulut, X. Yuan, B. Can, and F. Schneider, (2015). Thickness of the lithosphere beneath Turkey and surroundings from S-receiver functions, Solid Earth, 6, 971-984.

Kiratzi, A. (2002). Stress tensor inversions along the westernmost North Anatolian Fault Zone and its continuation into the North Aegean Sea, Geophys. J. Int., 151, 360-376.

Koukouvelas, I.K. and A. Aydin (2002). Fault structure and related basins of the North Aegean Sea and its surroundings, Tectonics, 21, ???????.

Kreemer, C., N. Chamot-Rooke, X. LePichon (2004). Constraints on the evolution and vertical coherency of deformation in the Northern Aegean from a comparison of geodetic, geologic and seismologic data, Earth Planet. Sci. Lett., 225, 329 - 346.

Kürçer, A., A. Chatzipetros, S. Z. Tutkun, S. Pavlides, Ö. Ateş, and S. Valkaniotis (2008). The Yenice- Gönen active fault (NW Turkey): Active tectonics and paleoseismology, Tectonophysics, 453, 263-275.

Le Pichon, X., N. Chamot-Rooke, and S. Lallemant (1995). Geodetic determination of the kinematics of central Greece with respect to Europe: Implications for eastern Mediterranean tectonics, J. Geophys. Res., 100, 12675 -12690 .

Le Pichon, X. and C. Kreemer (2010). The Miocene-to-Present Kinematic Evolution of the Eastern Mediterranean and Middle East and Its Implications for Dynamics, Annu. Rev. Earth Planet. Sci., 38, 323-51.

Lienert, B.R.E. and J. Havskov (1995). A computer program for locating earthquakes both locally and globally, Seismol. Res. Lett., 66, 26-36.

Lin, J. and R. S. Stein, (2004). Stress triggering in thrust and subduction earthquakes, and stress interaction between the southern San Andreas and nearby thrust and strike-slip faults, J. Geophys. Res., 109, B02303, 


\section{Ethem Görgün et al.}

doi:10.1029/2003JB002607.

Livaoğlu, R., M. Ö. Timurağaoğlu, C. Serhatoğlu, and M. S. Döven (2018). Damage during the 6-24 February 2017 Ayvacık (Çanakkale) earthquake swarm, Nat. Hazard Earth Sys, 18, 921-934.

Lu, Z., M. Wyss, and H. Pulpan (1997). Details of stress directions in the Alaska subduction zone from fault plane solutions, J. Geophys. Res., 102, 5385-5402.

Lund, B., and R. Slunga (1999). Stress tensor inversion using detailed microearthquake information and stability constraints: Application to Olfus in southwest Iceland, J. Geophys. Res., 104, 14.947-14.964.

McClusky, S., S. Balassanian, A. Barka, C. Demir, S. Ergintav, I. Georgiev, O. Gurkan, M. Hamburger, K. Hurst, H. Kahle, K. Kastens, G. Kekelidze, R. King, V. Kotzev, O. Lenk, S. Mahmoud, A. Mishin, M. Nadariya, A. Ouzounis, D. Paradissis, Y. Peter, M. Prilepin, R. Reilinger, I. Sanli, H. Seeger, A. Tealeb, M. N. Toksöz, and G.Veis (2000). Global positioning system constraints on plate kinematics and dynamics in the eastern Mediterranean and Caucasus. J. Geophys. Res., 105, 5695-5719.

McKenzie, D. (1978). Active Tectonics of the Alpine-Himalayan belt: the Aegean Sea and surrounding regions, Geophys. J. Int., 55, 217-254.

Mesimeri, M., C. Kourouklas, E. Papadimitriou, V. Karakostas, D. Kementzetzidou, D. (2018). Analysis of microseismicity associated with the 2017 seismic swarm near the Aegean coast of NW Turkey, Acta Geophysica, $66,479-495$.

Michael, A.J. (1984). Determination of stress from slip data: faults and folds, J. Geophys. Res., 89, 11517-11526.

Michael, A.J. (1987). Use of focal mechanisms to determine stress: a control study, J. Geophys. Res., 92, 357-368.

Michael, A.J. (1991). Spatial variations of stress within the 1987 Whittier Narrows, California, aftershock sequence: new techniques and results., J. Geophys. Res., 96, 6303-6319.

Michael, A.J., W. L. Ellsworth, and D. Oppenheimer (1990). Co-seismic stress changes induced by the 1989 Loma Prieta, California earthquake, Geophys. Res. Lett., 17, 1441-1444.

Nakano, M., H. Kumagai, and H. Inoue (2008). Waveform inversion in the frequency domain for the simultaneous determination of earthquake source mechanism and moment function, Geophys. J. Int., 173, 1000-1011.

Nakano, M., T. Yamashina, H. Kumagai, H. Inoue, and H. Sunarjo, (2010). Centroid moment tensor catalogue for Indonesia, Phys. Earth Planet. Int., 183, 456-467.

Nyst, M. and W. Thatcher (2004). New constraints on the active tectonic deformation of the Aegean, J. Geophys. Res., 109, B11406, doi:10.1029/2003JB002830.

Özden, S., S. Över, S. A. Poyraz, Y. Güneş, and A. Pınar (2018). Tectonic implications of the 2017 Ayvacık (Çanakkale) earthquakes, Biga Peninsula, NW Turkey, J. Asian Earth Sci., 154, 125-141.

Reasenberg, P.A. and R. W. Simpson (1992). Response of regional seismicity to the static stress change produced by the Loma Prieta earthquake, Science, 255, 1687-1690, doi:10.1126/science.255.5052.1687.

Reilinger, R., S. McClusky, P. Vernant, S. Lawrence, S., Ergintav, R. Cakmak, H. Ozener, F. Kadirov, I. Guliev, R. Stepanyan, M. Nadariya, G. Hahubia, S. Mahmoud, K. Sakr, A. ArRajehi, D. Paradissis, A. Al-Aydrus, M. Prilepin, T. Guseva, E. Evren, A. Dmitrotsa, S. V. Filikov, F. Gomez, R. Al-Ghazzi, and G. Karam (2006). GPS constraints on continental deformation in the Africa-Arabia-Eurasia continental collision zone and implications for the dynamics of plate interactions, J. Geophys. Res., 111, B05411, doi:10.1029/2005JB004051.

Selim, H.H. and O. Tüysüz, (2013). The Bursa-Gönen Depression, NW Turkey: a complex basin developed on the North Anatolian Fault, Geol. Mag. 150, 5, 801-821.

Şaroğlu, F., Ö. Emre, İ. Kuşcu (1992). Active Fault Map of Turkey, General Directorate of Mineral Research and Exploration (MTA), Eskisehir Yolu, 06520, Ankara, Turkey.

Şengör, A.M.C., N. Görür, and F. Şaroğlu (1985). Strike-slip faulting and related basin formation in zones of tectonic escape: Turkey as a case study, SEPM, 37, 227-264.

Svigkas, N., S. Atzori, A. Kiratzi, C. Tolomei, and S. Salvi, S. (2019). Isolation of swarm sources using InSAR: the case of the February 2017 seismic swarm in western Anatolia (Turkey), Geophys. J. Int, , 217, 3, 1479-1495.

Taymaz, T., J. A. Jackson, and D. McKenzie (1991). Active Tectonics of the North and Central Aegean Sea, Geophys. J. Int, 106, 433-490.

Toda, S., R. S. Stein, K. Richards-Dinger, and S. Bozkurt (2005). Forecasting the evolution of seismicity in southern California: Animations built on earthquake stress transfer, J. Geophys. Res., 110, B05S16, doi:10.1029/2004JB003415.

Toda, S., J. Lin, M. Meghraoui, and R. S. Stein (2008). 12 May 2008 M = 7.9 Wenchuan, China, earthquake calculated 
to increase failure stress and seismicity rate on three major fault systems, Geophys. Res. Lett., 35, L17305, doi:10.1029/2008GL034903.

Toda, S., R. S. Stein and J. Lin (2011a). Widespread seismicity excitation throughout central Japan following the $2011 \mathrm{M}=9.0$ Tohoku earthquake and its interpretation by Coulomb stress transfer, Geophys. Res. Lett., 38, L00G03, doi:10.1029/2011GL047834.

Toda, S., R. S. Stein, V. Sevilgen, and J. Lin (2011b). Coulomb 3.3 Graphic-Rich Deformation and.Stress-Change Software for Earthquake, Tectonic, and Volcano Research and Teaching-User Guide, Open-File Report 2011 -1060, U.S. Department of the Interior, U.S. Geological Survey.

Vanacore, E. A, T. Taymaz, and E. Saygin (2013). Moho Structure of the Anatolian Plate from Receiver Function Analysis, Geophys. J. Int., 193, 1, 329-337, doi:10.1093/gii/ggs107, 9 pp +15 pages supporting online material.

Wallace, R.E. (1951). Geometry of shearing stress and relationship to faulting. J Geol., 59,118-130.

Waldhauser, F., and W. L. Ellsworth (2000). A double-difference earthquake location algorithm: method and application to the Northern Hayward fault, California, B. Seismol. Soc. Am., 90, 1353-1368.

Vavryčuk, V. (2014). Iterative joint inversion for stress and fault orientations from focal mechanisms, Geophys. J. Int., 199, 69-77, doi:10.1093/gji/ggu224.

Wessel, P. and W. H. F. Smith (1998). New, improved version of the Generic Mapping Tools Released, EOS Trans., AGU, $79,579$.

Wiemer, S., M. C. Gerstenberger, and E. Hauksson (2002). Properties of the 1999, Mw 7.1, Hector Mine earthquake: Implications for aftershock hazard, B. Seismol. Soc. Am.,, 92, 1227-1240.

Yaltırak, C., E. B. İşler, A. E. Aksu, and R. N. Hiscott (2012). Evolution of the Bababurnu Basin and shelf of the Biga Peninsula: western extension of the middle strand of the North Anatolian Fault Zone, Northeast Aegean Sea, Turkey, J. Asian Earth Sci., 57, 103-119.

Zang, A., and O. Stephansson (2010). Stress Field of the Earth's Crust, Springer Science + Business Media B.V., Dordrecht.

Zoback, M.L. (1992). First and second order patterns of stress in the lithosphere: the world stress map project, J. Geophys.Res., 97, 11,703-11,728.

*CORRESPONDING AUTHOR: Ethem GÖRGÜN,

Department of Geophysical Engineering, Istanbul University-Cerrahpaşa, Büyükçekmece Campus, 34500, 